\title{
Role of hepcidin in oxidative stress and cell death of cultured mouse renal collecting duct cells: protection against iron and sensitization to cadmium
}

\author{
Stephanie Probst ${ }^{1} \cdot$ Johannes Fels $^{1} \mathbb{D} \cdot$ Bettina Scharner $^{1} \cdot$ Natascha A. Wolff $^{1} \cdot$ Eleni Roussa $^{2} \mathbb{D}$. \\ Rachel P. L. van Swelm ${ }^{3}$ (D) Wing-Kee Lee ${ }^{1,4}$ (D) Frank Thévenod ${ }^{1}$ (D)
}

Received: 12 February 2021 / Accepted: 17 June 2021 / Published online: 28 June 2021

(c) The Author(s) 2021

\begin{abstract}
The liver hormone hepcidin regulates systemic iron homeostasis. Hepcidin is also expressed by the kidney, but exclusively in distal nephron segments. Several studies suggest hepcidin protects against kidney damage involving $\mathrm{Fe}^{2+}$ overload. The nephrotoxic non-essential metal ion $\mathrm{Cd}^{2+}$ can displace $\mathrm{Fe}^{2+}$ from cellular biomolecules, causing oxidative stress and cell death. The role of hepcidin in $\mathrm{Fe}^{2+}$ and $\mathrm{Cd}^{2+}$ toxicity was assessed in mouse renal cortical $[\mathrm{mCCD}(\mathrm{cl} .1)]$ and inner medullary $\left[\mathrm{mIMCD}_{3}\right]$ collecting duct cell lines. Cells were exposed to equipotent $\mathrm{Cd}^{2+}(0.5-5 \mu \mathrm{mol} / \mathrm{l})$ and/or $\mathrm{Fe}^{2+}(50-100 \mu \mathrm{mol} / \mathrm{l})$ for 4-24 h. Hepcidin (Hampl) was transiently silenced by RNAi or overexpressed by plasmid transfection. Hepcidin or catalase expression were evaluated by RT-PCR, qPCR, immunoblotting or immunofluorescence microscopy, and cell fate by MTT, apoptosis and necrosis assays. Reactive oxygen species (ROS) were detected using CellROX ${ }^{\mathrm{TM}}$ Green and catalase activity by fluorometry. Hepcidin upregulation protected against $\mathrm{Fe}^{2+}$-induced $\mathrm{mIMCD}_{3}$ cell death by increasing catalase activity and reducing ROS, but exacerbated $\mathrm{Cd}^{2+}$-induced catalase dysfunction, increasing ROS and cell death. Opposite effects were observed with Hampl siRNA. Similar to Hampl silencing, increased intracellular $\mathrm{Fe}^{2+}$ prevented $\mathrm{Cd}^{2+}$ damage, ROS formation and catalase disruption whereas chelation of intracellular $\mathrm{Fe}^{2+}$ with desferrioxamine augmented $\mathrm{Cd}^{2+}$ damage, corresponding to hepcidin upregulation. Comparable effects were observed in $\mathrm{mCCD}(\mathrm{cl} .1)$ cells, indicating equivalent functions of renal hepcidin in different collecting duct segments. In conclusion, hepcidin likely binds $\mathrm{Fe}^{2+}$, but not $\mathrm{Cd}^{2+}$. Because $\mathrm{Fe}^{2+}$ and $\mathrm{Cd}^{2+}$ compete for functional binding sites in proteins, hepcidin affects their free metal ion pools and differentially impacts downstream processes and cell fate.
\end{abstract}

Keywords DFO $\cdot$ Metallothionein $\cdot \mathrm{Ca}_{\mathrm{v}} 3.1 \cdot \mathrm{DMT} 1$

Frank Thévenod

frank.thevenod@uni-wh.de

1 Faculty of Health, Institute of Physiology, Pathophysiology and Toxicology and ZBAF (Centre for Biomedical Education and Research), School of Medicine, Witten/Herdecke University, Stockumer Str 12 (Thyssenhaus), 58453 Witten, Germany

2 Department of Molecular Embryology, Faculty of Medicine, Institute of Anatomy and Cell Biology, University of Freiburg, Albertstr. 17, 79104 Freiburg, Germany

3 Department of Laboratory Medicine, Radboud Institute for Molecular Life Sciences, Radboud University Medical Center, Geert Grooteplein 10, 6525 GA Nijmegen, The Netherlands

4 AG Physiology and Pathophysiology of Cells and Membranes, Medical School OWL, Bielefeld University, Morgenbreede 1, 33615 Bielefeld, Germany

\section{Introduction}

Synthesis and secretion of the systemic iron-regulatory hormone hepcidin (rodent gene name Hampl) by the liver is regulated by iron stores within macrophages, inflammation, hypoxia, and erythropoiesis (reviewed in Ganz and Nemeth 2012). Binding of circulating hepcidin to its target protein ferroportin- 1 on enterocytes and macrophages leads to internalization and degradation of the hepcidin-ferroportin-1 complex by ubiquitination, thereby inhibiting the efflux of iron from intestinal enterocytes into the blood as well as preventing the release of stored iron from macrophages (Nemeth et al. 2004). Together, these effects result in a decrease in circulating iron levels.

The kidney has recently emerged as an organ with a significant role in systemic iron homeostasis (Thévenod 
and Wolff 2016). Substantial amounts of iron are filtered by the kidney and have to be reabsorbed to prevent iron deficiency. Accordingly, iron transporters and receptors for protein-bound iron are expressed in the nephron (reviewed in Martines et al. 2013; Smith and Thévenod 2009; Thévenod and Wolff 2016). Systemic iron overload induced by genetic diseases, such as hereditary haemochromatosis or $\beta$-thalassemia major result in renal iron deposition and kidney injury involving oxidative stress induced by the Fenton metal ion $\mathrm{Fe}^{2+}$ (Halliwell and Gutteridge 2015), various forms of cell death or inflammation (reviewed in van Swelm et al. 2020). It is intriguing that hepcidin is also locally expressed in various organs, including the kidney where it is found in the distal nephron, but not in the proximal tubule (PT) (Kulaksiz et al. 2005). Although several studies indicate that hepcidin protects against certain forms of kidney injury caused by oxidative stress (Scindia et al. 2015; van Swelm et al. 2016, 2018), and possibly interferes with cell death signaling or chelates $\mathrm{Fe}^{2+}$ (Farnaud et al. 2006, 2008; Gerardi et al. 2005), the function of hepcidin locally expressed in the distal nephron is not understood.

Cadmium $\left(\mathrm{Cd}^{2+}\right)$ is a non-essential transition metal, which is taken up from the environment into the body through pulmonary and enteral pathways (Jarup and Akesson 2009). The kidney PT is a major target of $\mathrm{Cd}^{2+}$ toxicity by chronic (low) $\mathrm{Cd}^{2+}$ exposure (reviewed in Thévenod 2003, 2009). Renal dysfunction develops in up to $7 \%$ of the general population, and in its most severe form displays major features of renal Fanconi syndrome (Johri et al. 2010). Although $\mathrm{Cd}^{2+}$ is not a Fenton metal ion, it also increases cellular reactive oxygen species (ROS) formation, e.g., by disrupting ROS metabolizing enzymes (reviewed in Cuypers et al. 2010), which alters their anti-oxidative redox signature and leads to apoptotic and/or necrotic cell death, as happens in PT cells (Nair et al. 2015). The renal medulla also accumulates significant amounts of $\mathrm{Cd}^{2+}$ in humans and concentrations of $\mathrm{Cd}^{2+}$ can reach $\sim 50 \%$ of the levels found in the cortex (Nagamine et al. 2007; Torra et al. 1994; Wang et al. 2009; Yoshida et al. 1998), although nephrotoxicity is less apparent (Johri et al. 2010). $\mathrm{Cd}^{2+}$ has similar bioinorganic chemical characteristics as $\mathrm{Fe}^{2+}$, and it can displace $\mathrm{Fe}^{2+}$ from its physiological binding sites (including $\mathrm{Fe}^{2+}$ transporters) to disrupt cellular functions and cause damage (reviewed in Moulis 2010). Indeed, the distal nephron expresses a variety of $\mathrm{Cd}^{2+}$ entry pathways, including iron response element (IRE)-regulated $\mathrm{Fe}^{2+}$ transporters (reviewed in Smith and Thévenod 2009; Thévenod and Wolff 2016).

Consequently, we assessed roles of hepcidin in $\mathrm{Fe}^{2+}$ - and $\mathrm{Cd}^{2+}$-induced ROS formation and cell injury in the mouse kidney cortical and inner medullary collecting duct (CD) cell lines $\mathrm{mCCD}(\mathrm{cl} .1)$ and $\mathrm{mIMCD}_{3}$.

\section{Materials and methods}

\section{Experimental solutions}

A $\mathrm{CdCl}_{2}$ stock solution (Merck; cat. \# 2011; $2.5 \mathrm{mM}$ dissolved in $\mathrm{ddH}_{2} \mathrm{O}$ ) was used throughout the study and diluted 1:500-1:1000 in serum-free medium. Iron salts and $\mathrm{Na}^{+}$-ascorbate stock solutions were freshly prepared for each experiment. Stock solutions were as follows: $\mathrm{FeSO}_{4}$ (Sigma-Aldrich; cat. \# F8048) or $\mathrm{FeCl}_{3}$ (SigmaAldrich; cat. \# 157740), $5 \mathrm{mM}$ in $\mathrm{dd}_{2} \mathrm{O}$ or in $500 \mathrm{mM}$ $\mathrm{Na}^{+}$-ascorbate, pH 7.4 where ascorbic acid $\left(\mathrm{C}_{6} \mathrm{H}_{8} \mathrm{O}_{6}\right)$ (Sigma-Aldrich; cat. \# A5960) was dissolved in $\mathrm{ddH}_{2} \mathrm{O}$, $\mathrm{pH}$ titrated to 7.4 with $1 \mathrm{M} \mathrm{NaOH}$ and final volume adjusted to obtain a $500 \mathrm{mM}$ stock solution. Stock solutions of iron salts and $\mathrm{Na}^{+}$-ascorbate were diluted 1:50 or 1:100 in serum-free medium for individual experiments. Stock solutions of $10 \mathrm{mmol} / \mathrm{l}$ desferrioxamine mesylate salt (Sigma-Aldrich; cat. \# D9533) dissolved in phosphatebuffered saline (PBS) were freshly prepared prior to use.

\section{Cell culture}

The immortalized mouse kidney medulla $\mathrm{CD}$ cell line $\mathrm{mIMCD}_{3}$, was obtained from ATCC (cat. \# ATCC CRL2123). The $\mathrm{mCCD}(\mathrm{cl} .1)$ cell line clone was originally derived from primary cultures of cortical CD microdissected from mouse kidney (Gaeggeler et al. 2005) and was obtained from Dr. Edith Hummler (University of Lausanne, CH). WKPT-0293 Cl.2 cells, an immortalized cell line from the $\mathrm{S} 1$ segment of rat PT, was obtained from Dr. Ulrich Hopfer (Case Western, Reserve University, Cleveland, OH, USA) (Woost et al. 1996). mIMCD $_{3}$ cells were cultured in Dulbecco's modified Eagle's medium (DMEM)/nutrient mixture F-12 (1:1) (GibCo; cat. \# 31330 ) supplemented with $10 \%$ fetal bovine serum (FBS) (Gibco; cat. \# 10270-106), $50 \mathrm{U} / \mathrm{ml}$ penicillin, and $50 \mu \mathrm{g} /$ $\mathrm{ml}$ streptomycin (Gibco; cat. \#15140-122). mCCD(cl.1) cells were cultured in DMEM/F-12 (1:1) supplemented with 5\% FBS, $100 \mathrm{U} / \mathrm{ml}$ penicillin, and $100 \mu \mathrm{g} / \mathrm{ml}$ streptomycin, $0.9 \mu \mathrm{mol} / \mathrm{l}$ insulin (Sigma-Aldrich; cat. \# I1882), $5 \mu \mathrm{g} / \mathrm{ml}$ apo-transferrin (Sigma-Aldrich; cat. \# T2252), $10 \mathrm{ng} / \mathrm{ml}$ EGF (Sigma-Aldrich; cat. \# E9644), $1 \mathrm{nM}$ T3 (Sigma-Aldrich; cat. \# T6397), and $50 \mathrm{nM}$ dexamethasone (Sigma-Aldrich; cat. \# D4902) (Fila et al. 2011). WKPT$0293 \mathrm{Cl} .2$ cells were cultured in medium essentially as previously described (Lee et al. 2005). All cell lines were used at passage numbers $20-40$ and cultured in 25 or 75 
$\mathrm{cm}^{2}$ standard tissue culture flasks (Sarstedt) at $37^{\circ} \mathrm{C}$ in a humidified $5 \% \mathrm{CO}_{2}$ atmosphere and passaged twice a week upon reaching $\sim 80-90 \%$ confluency.

\section{Animals}

Six- to eight-week-old C57BL/6 mice of either sex (Charles River Laboratories) were provided food and water ad libitum and maintained through a 12-12 $\mathrm{h}$ light-dark cycle in a climatecontrolled environment. Animal handling and euthanasia were performed in accordance with the recommendations of German Ethical Guidelines for Laboratory Animals and the European Directive on the Protection of Animals used for Scientific Purposes (2010/63/EU). Protocols were approved by the Governmental Animal Ethics Committee of North-Rhine-Westphalia, Germany (Landrat Ennepe-Ruhr-Kreis, file number 32/7 from January 20, 2014) and the Institutional Animal Care and Use Committee of the University of Freiburg and the ethics committee of the City of Freiburg (authorization: X18/08C). All efforts were made to minimize the number of animals used and their suffering. Mice were anaesthetized with $\mathrm{CO}_{2}$ and/or sacrificed by cervical dislocation, and kidneys were immediately excised. For qPCR and immunoblotting, kidney cortex was grossly separated from medulla by surgery using a scalpel and razor blades.

\section{Transient transfections}

Transient transfection of Hampl siRNA or expression plasmid were performed according to manufacturers' protocols. In brief, $100 \mathrm{nM}$ mouse Hampl (Hamp1si) (SigmaAldrich; cat \# EMU174481) or $100 \mathrm{nM}$ control siRNA (ctrlsi) (Eurogentec, cat. \# SR-CL000-005) was mixed with Lipofectamine RNAiMAX (Thermo Fisher Scientific) in Opti-MEM I (Gibco) and incubated for $5 \mathrm{~min}$ at room temperature (RT). For PCR analyses, 10-100 nM siRNA was used. For plasmid transfection, 0.5-1.25 $\mu \mathrm{g}$ mouse Hamp1 plasmid (Origene, cat. \# MC211974) or control plasmid were mixed with Lipofectamine 2000 (Thermo Fisher Scientific) in Opti-MEM I and incubated for $10 \mathrm{~min}$ at RT prior to transfection in $0.5-1 \mathrm{ml}$ culture medium. For Hamp 1 gene silencing or overexpression, cells were exposed for $6 \mathrm{~h}$ to siRNA or plasmid solutions in fresh serum-free standard medium without antibiotics. Medium was then replaced by siRNA- and serum-containing or serum-free medium with antibiotics and cultured for up to additional $18 \mathrm{~h}(24 \mathrm{~h}$ in total with or without experimental treatments). For hepcidin immunofluorescence staining in $\mathrm{mCCD}(\mathrm{cl} .1)$, a different protocol was used: after transfection with siRNA for $6 \mathrm{~h}$ in serum-free medium, cells were cultured for additional $18 \mathrm{~h}$ in standard serum-containing medium with antibiotics before exposure to serum-free medium for $6 \mathrm{~h}$ with or without $\mathrm{Cd}^{2+}$.

\section{RNA extraction, CDNA synthesis and RT-PCR}

Cells were plated and cultured for $24-48 \mathrm{~h}$ up to a confluency of $50 \%$ prior to treatments and/or transfection (as described above), harvested by scraping and subjected to isolation of total RNA and synthesis of cDNA as previously described (Betten et al. 2018). Cell numbers used for seeding and multiwell culture plate formats are summarized in Suppl. Table 1 for all cell lines and assays. RNA was isolated from mouse cortex and medulla tissue samples using High Pure RNA Tissue Kit (Roche; cat. \# 12033674001) according to manufacturer's protocol prior to cDNA synthesis. PCR reactions were performed using specific primers and cycling protocols (Table 1). Primers

Table 1 Protocols for reverse transcriptase-PCR

\begin{tabular}{|c|c|c|c|c|}
\hline & Gapdh & Hampl & Cat & Cat \\
\hline Species & Mus musculus & Mus musculus & Mus musculus & Rattus norvegicus \\
\hline Accession number & NM_001289726.1 & NM_032541.2 & NM_009804.3 & NM_012520.2 \\
\hline Forward primer $\left(5^{\prime}-3^{\prime}\right)$ & $\begin{array}{l}\text { AGGGCTCATGACCAC } \\
\text { AGT }\end{array}$ & $\begin{array}{l}\text { TTGCGATACCAATGC } \\
\text { AGAAG }\end{array}$ & $\begin{array}{l}\text { GCAGATACCTGTGAA } \\
\text { CTGTC }\end{array}$ & $\begin{array}{l}\text { GCGAATGGAGAGGCA } \\
\text { GTGTAC }\end{array}$ \\
\hline Reverse primer $\left(5^{\prime}-3^{\prime}\right)$ & $\begin{array}{l}\text { TGCAGGGATGATGTT } \\
\text { CTG }\end{array}$ & $\begin{array}{l}\text { GGATGTGGCTCTAGG } \\
\text { CTATGTT }\end{array}$ & $\begin{array}{l}\text { GTAGAATGTCCGCAC } \\
\text { CTGAG }\end{array}$ & $\begin{array}{l}\text { GAGTGACGTTGTCTTCAT } \\
\text { TAGCACTG }\end{array}$ \\
\hline Reference & NCBI Primer-BLAST & van Swelm et al. (2016) & El Mouatassim et al. (1999) & Limaye et al. (2003) \\
\hline Activation & $5 \min 95^{\circ} \mathrm{C}$ & $5 \min 95^{\circ} \mathrm{C}$ & $5 \min 95^{\circ} \mathrm{C}$ & $5 \min 95^{\circ} \mathrm{C}$ \\
\hline Cycle number & $18-22$ & $30-34$ & 35 & 26 \\
\hline Denaturation & $30 \mathrm{~s} 94^{\circ} \mathrm{C}$ & $30 \mathrm{~s} 94^{\circ} \mathrm{C}$ & $45 \mathrm{~s} 94^{\circ} \mathrm{C}$ & $30 \mathrm{~s} 94^{\circ} \mathrm{C}$ \\
\hline Annealing & $30 \mathrm{~s} 60^{\circ} \mathrm{C}$ & $30 \mathrm{~s} 60^{\circ} \mathrm{C}$ & $60 \mathrm{~s} 56^{\circ} \mathrm{C}$ & $30 \mathrm{~s} 58^{\circ} \mathrm{C}$ \\
\hline Extension & $30 \mathrm{~s} 72^{\circ} \mathrm{C}$ & $30 \mathrm{~s} 72^{\circ} \mathrm{C}$ & $60 \mathrm{~s} 72^{\circ} \mathrm{C}$ & $30 \mathrm{~s} 72^{\circ} \mathrm{C}$ \\
\hline Final Extension & $7 \min 72^{\circ} \mathrm{C}$ & $7 \min 72^{\circ} \mathrm{C}$ & $7 \min 72^{\circ} \mathrm{C}$ & $7 \min 72^{\circ} \mathrm{C}$ \\
\hline PCR product (bp) & 112 & 125 & 229 & 652 \\
\hline
\end{tabular}


were designed using PrimerBLAST software (NCBI) and/ or taken from the literature and synthesized by Eurofins Genomics. Gel documentation and densitometry analysis were performed using Image Lab Software version 5.2 (Bio-Rad Laboratories), with correction for loading by the housekeeping gene glyceraldehyde-3-phosphate dehydrogenase (Gapdh).

\section{qPCR}

Cells were grown to confluence, treated \pm transfection (see above and Suppl. Table 1), harvested by scraping and subjected to RNA isolation and cDNA synthesis as previously described (Betten et al. 2018). Target sequences were amplified by qPCR, essentially as described (Betten et al. 2018), in a StepOnePlus Real-Time PCR System (Applied Biosystems), using KAPA SYBR FAST qPCR Master Mix Universal with high ROX reference dye (Sigma-Aldrich). The following primers were used for amplification: rat and mouse Hampl, forward 5'-GCTGCCTGTCTCCTGCTT-3', reverse 5'-TTACAGCATTTACAGCAGAAGAGG-3' (Kanamori et al. 2014); mouse Hamp1, forward 5'-TTGCGATAC CAATGCAGAAG-3', reverse 5'-GGATGTGGCTCTAGGCTA TGTT-3' (van Swelm et al. 2016); rat and mouse Gapdh, forward 5'-AGGGCTCATGACCACAGT-3', reverse 5'-TGC AGGGATGATGTTCTG-3' (NCBI Primer-BLAST); mouse Gapdh, forward 5'-CGGCCGCATCTTCTTGTG-3', reverse 5'-CCGACCTTCACCATTTTGTCTAC-3' (NCBI PrimerBLAST); mouse Actb, forward 5'-CGTGCGTGACATCAA AGAGAA-3', reverse 5'-GGCCATCTCCTGCTCGAA-3' (Betten et al. 2018); mouse Cat, forward 5'-GCAGATACC TGTGAACTGTC-3', reverse 5'-GTAGAATGTCCGCACCTG $A G-3^{\prime}$ (El Mouatassim et al. 1999); rat Cat, forward 5'-GCG AATGGAGAGGCAGTGTAC-3', reverse 5'-GAGTGACGT TGTCTTCATTAGCACTG-3' (Limaye et al. 2003). Primers were used at $300 \mathrm{nM}$ final concentration. The cycling conditions were activation at $95^{\circ} \mathrm{C}$ for $5 \mathrm{~min}$ followed by 40 cycles of $95^{\circ} \mathrm{C}$ for $3 \mathrm{~s}$ and $60^{\circ} \mathrm{C}$ for $30 \mathrm{~s}\left(56^{\circ} \mathrm{C}\right.$ for mouse Cat and $58^{\circ} \mathrm{C}$ for rat $\mathrm{Cat}$ ), with melt curve analysis to check amplification specificity. Gene expression levels were calculated according to the $2^{-\Delta \mathrm{Cq}}$ method relative to the sample with the highest expression (minimum Cq) (Bustin et al. 2009). The data obtained were corrected to the expression of two stable reference genes: Gapdh and Actb.

\section{Surface biotinylation}

Cell surface proteins were isolated using the Pierce ${ }^{\mathrm{TM}}$ Cell Surface Protein Isolation Kit (Thermo Fisher Scientific; cat. \# 89881), with some modifications. After biotinylation and quenching, cells were disrupted by nitrogen pressure cavitation at $350 \mathrm{lb}$ per square inch for $2.5 \mathrm{~min}$ in a cell disruptor (Parr Instrument Company) followed by centrifugation of the homogenate at $1000 \times g$ for $10 \mathrm{~min}$ to remove nuclei and cellular debris, and the resulting supernatant was centrifuged at $15,000 \times g$ for $15 \mathrm{~min}$ to remove mitochondria. The remaining membranes in the supernatant were pelleted at $100,000 \times \mathrm{g}$ for $45 \mathrm{~min}$, subjected to a $15 \mathrm{~min}$ wash with $250 \mathrm{mM} \mathrm{KBr}$ to remove membrane-associated proteins and enrich transmembrane proteins, and centrifuged again at $100,000 \times g$ for $45 \mathrm{~min}$. The resulting pellet was resuspended in kit lysis buffer and isolation of biotinylated proteins was continued according to the manufacturer's protocol. All procedures were carried out at $4^{\circ} \mathrm{C}$.

\section{Immunoblotting}

Sodium dodecyl sulfate polyacrylamide gel electrophoresis (SDS-PAGE) and immunoblotting were essentially performed according to standard procedures using rapid semi-dry transfer (Bio-Rad Laboratories Trans-Blot Turbo). Homogenization of cells and mouse kidney cortex or medulla was performed by sonication (Branson 450 Digital Sonifier) in isosmotic sucrose buffer supplemented with protease inhibitor cocktail (Sigma-Aldrich). Homogenates were centrifuged for $5 \mathrm{~min}$ at $500 \times g$ to remove unbroken cells, and the supernatant was collected for determination of protein concentrations by the Bradford method, using bovine serum albumin (BSA) as standard (Bradford 1976). Samples were mixed with Laemmli buffer and heated for $5 \mathrm{~min}$ at $95^{\circ} \mathrm{C}$ [or for $15 \mathrm{~min}$ at $65^{\circ} \mathrm{C}$ for immunodetection of divalent metal transporter 1 (DMT1)] and subjected to SDS-PAGE and immunoblotted. Primary anti-catalase (cat. \# ab209211 or cat. \# ab16731; $1: 2,000$ ) and anti- $\beta$-actin (cat. \# A5316; 1:20,000) antibodies were obtained from Abcam and SigmaAldrich, respectively. Anti-PARP (cat. \# 9542; Cell Signaling Technology) was diluted 1:3000. Anti-calcium channel $\mathrm{Ca}_{\mathrm{V}} 3.1(\alpha 1 \mathrm{G})$ (Sigma-Aldrich; cat. \# C2240) was diluted 1:400. A rabbit polyclonal anti-rat DMT1 directed against the peptide sequence MVLDPEEKIPDDGASGDHGDS (Ferguson et al. 2001) generated by ImmunoGlobe GmbH (designated 1102\#3) detects all four major DMT1 isoforms and was used at a concentration of $0.5 \mu \mathrm{g} / \mathrm{ml}$. Horseradish peroxidase-conjugated secondary antibodies were purchased from Jackson ImmunoResearch Europe Ltd and used at a dilution of 1:10,000. Immunoblots were developed using Immobilon ECL substrate (Millipore; cat. \# WBKLS0500) and visualized on blue X-ray films (Carestream). Densitometry analysis was performed using FIJI/ImageJ software (Schneider et al. 2012).

\section{Catalase assay}

Cells were plated and cultured for $24 \mathrm{~h}$ up to a confluency of $50 \%$ prior to treatments and/or transfection, as described above (see Suppl. Table 1). Cells were harvested by scraping 
into PBS and collected by centrifugation at $2000 \times g$ for $1.5 \mathrm{~min}$ at $4^{\circ} \mathrm{C}$. Catalase activity was determined using a Catalase Fluorometric Detection Kit (Enzo Life Sciences, Inc.; cat. \# ADI-907-027) according to the manufacturer's instructions. Cell pellets were resuspended in $55 \mu \mathrm{l}$ of $1 \mathrm{X}$ reaction buffer and lysed by five freeze/thaw cycles. To fall within the standard curve range, samples were diluted to $0.25-1.0 \mu \mathrm{g}$ protein. Samples were measured at $\lambda_{\text {ex }} 530 \mathrm{~nm}$ $\lambda_{\mathrm{em}} 590 \mathrm{~nm}$ in a Mithras LB 940 Multimode Microplate Reader (Berthold Technologies) by repeated measurements every minute for $10 \mathrm{~min}$. Catalase activity was determined from the standard curve performed in each experiment.

\section{Cell viability and cell death assays}

Cells were plated and cultured for $24-72 \mathrm{~h}$ prior to treatments and/or transfection, as described above (see Suppl. Table 1). Cell viability was determined by the MTT test, as previously described (Lee et al. 2005). Trypan blue exclusion was used as a test for necrosis. Detached cells in the medium and adherent cells were collected, diluted 1:2 with $0.4 \%$ trypan blue and automatically counted (Countess II FL, Thermo Fisher Scientific). Apoptosis was detected using the APOSTRAND ${ }^{\mathrm{TM}}$ ELISA Apoptosis Detection Kit (Enzo Life Sciences, Inc.; cat. \# BML-AK120) according to the manufacturer's protocol. The APOSTRAND ${ }^{\text {TM }}$ ELISA is based on the sensitivity of DNA in apoptotic cells to formamide denaturation and the detection of the denatured DNA with a monoclonal antibody to single-stranded DNA (ssDNA). Treatments were performed in FBS-free medium without phenol red. FBS-free medium without phenol red or PBS were used as negative controls whereas ssDNA included in the APOSTRAND ${ }^{\text {TM }}$ ELISA served as a positive control.

\section{Immunofluorescence microscopy}

$0.5-6 \times 10^{4} \mathrm{mIMCD}_{3}$ or $\mathrm{mCCD}(\mathrm{cl} .1)$ cells $/ \mathrm{cm}^{2}$ were plated onto untreated or polylysine-treated glass coverslips in standard growth medium and stained 1-3 days later, essentially as described previously (Wolff et al. 2008). Unless otherwise indicated, all immunostaining procedures were performed at RT. In brief, cells were washed 2-3 times with $\mathrm{Ca}^{2+}$ and $\mathrm{Mg}^{2+}$ containing PBS, fixed with $2-4 \%$ paraformaldehyde (PFA) in PBS for 10-15 min, permeabilized with $0.1-0.5 \%$ Triton X-100 for $15 \mathrm{~min}$ (or $1 \%$ SDS for $5 \mathrm{~min}$ for hepcidin) and blocked with $1 \%$ bovine serum albumin in PBS (BSA-PBS) for $30 \mathrm{~min}$. Cells were incubated with rabbit polyclonal anti-Ca $\mathrm{V}_{\mathrm{V}} 3.1$ (Sigma-Aldrich; cat. \# C2240; 1:250) and diluted in BSA-PBS overnight at $4^{\circ} \mathrm{C}$. Alternatively, coverslips were stained either for metallothionein (MT) with mouse anti-MT clone E9 antibody (Dako; cat. \# M0639; 1:500) in BSA-PBS for 90 min, or with rabbit polyclonal anti-hepcidin antibody (Abcam; cat. \#ab30760; $1: 100$ ) in BSA-PBS for $2 \mathrm{~h}$. After washout of primary antibodies, coverslips were incubated with anti-mouse or antirabbit Alexa Fluor ${ }^{\circledR} 488$-conjugated secondary antibody (Thermo Fisher Scientific; cat. \# A-11029 or A-11008; 1:400-1:500) in BSA-PBS for 45-60 min at RT. Nuclei were counterstained with $0.8 \mu \mathrm{g} / \mathrm{ml} 2$ '-(4-ethoxyphenyl)-5(4-methyl-L-piperazinyl)-2,5'-bi-1H-benzimidazole, $3 \mathrm{HCl}$ (H-33342) (Calbiochem) for $5 \mathrm{~min}$, and coverslips mounted with DAKO fluorescence mounting medium (Dako).

Conventional fluorescence microscopy was performed using a Zeiss Axiovert 200M epifluorescence microscope (Carl Zeiss) equipped with Fluar 40x/N.A. 1.3 and 100x/N.A. 1.3 oil immersion objectives, a Sola SM II light engine (Lumencor), filters for Alexa Fluor ${ }^{\circledR} 488$ (green) and $\mathrm{H}-33342$ (blue) with excitation/emission wavelengths of $480 \pm 20 / 535 \pm 25 \mathrm{~nm}$, and $360 \pm 20 / 460 \pm 25 \mathrm{~nm}$, respectively, and a Cool-SNAP ES CCD camera (Roper Scientific) or a pco.panda 4.2 camera (PCO). Images were acquired at fixed exposure times at the focal plane of highest contrast and analyzed with MetaMorph software (Universal Imaging), as described elsewhere (Abouhamed et al. 2006), unless otherwise indicated. Confocal images were acquired using a TCS SP5 laser scanning confocal microscope (Leica) with a Plan-Apochromat 63x/N.A.1.4 oil immersion objective (Leica) and an argon (488 nm) laser and analyzed using LAS AF software.

\section{Immunofluorescence staining of tissue sections}

For immunostaining, kidneys were cut into pieces and fixed with PLP (periodate/lysine/paraformaldehyde) overnight. Subsequently, tissue was cryoprotected in $15 \%$ and $30 \%$ sucrose, frozen in liquid nitrogen, and cut into $10 \mu \mathrm{m}$ cryosections. Cryosections were washed with PBS, treated with $1 \%$ SDS/PBS for 5 min, blocked with $1 \%$ BSA-PBS for $15 \mathrm{~min}$ at RT and incubated with primary anti-catalase rabbit antibody (Abcam; cat. \# ab209211; 1:1,000) in blocking solution overnight at $4^{\circ} \mathrm{C}$. After washing with PBS, slides were incubated with donkey anti-rabbit IgG Alexa Fluor 594 (Thermo Fisher Scientific; cat. \# A-11012; 1:400) for $1 \mathrm{~h}$ at RT. Slides were washed with PBS and mounted with Fluoromount-G (Southern Biotech; cat. \# 0100-20) for nuclear staining. Slides were viewed using a TCS SP8 confocal laser scanning microscope with Plan-Apochromat CS2 20x/0.75NA IMM or CS2 40x/1.30NA oil immersion objective (Leica) and an OPSL (552 nm) laser.

\section{Detection of ROS formation using CellROX ${ }^{\mathrm{TM}}$ green}

$\mathrm{mIMCD}_{3}$ cells were plated on glass coverslips and cultured for $72 \mathrm{~h}$ up to a confluency of $80 \%$ prior to treatments and/ or transfection, as described above (see also Suppl. Table 1). 
Cells were incubated with $5 \mu \mathrm{M}$ CellROX ${ }^{\mathrm{TM}}$ Green reagent (Thermo Fisher Scientific; cat. \# C10444) for $30 \mathrm{~min}$ at $37^{\circ} \mathrm{C}$. After washing with PBS containing $\mathrm{Ca}^{2+} / \mathrm{Mg}^{2+}$, cells were fixed with $3.7 \%$ PFA for 15 min at RT, washed with PBS, nuclei were counterstained with $0.8 \mu \mathrm{g} / \mathrm{ml} \mathrm{H}-33342$ for $5 \mathrm{~min}$, and coverslips were mounted with DAKO fluorescence mounting medium. Images were acquired with fixed exposure times at the focal plane of highest contrast and were analyzed with MetaMorph, as described above.

\section{Quantification of fluorescence images}

Quantification of fluorescence images was carried out using FIJI/Image J (Schindelin et al. 2012) or MetaMorph software, as described previously (Wolff et al. 2006). In brief, intensity thresholds were set to exclude cell-free regions. The mean fluorescence intensity per image was divided by the number of nuclei in the image to obtain average cellular fluorescence intensity. To correct for endogenous autofluorescence, intensity of negative control images, i.e., cells stained without primary antibody, was subtracted from all mean values.

\section{Statistics}

Unless otherwise indicated, the experiments were repeated at least three times with independent cultures. Statistical analyses were performed with GraphPad Prism v. 5.01 software (GraphPad Software Inc.) and all data sets were tested for parametric/non-parametric distribution. Bar diagrams showing means \pm SD were used for parametric data sets and box plots presenting 25 and 75 percentiles and median (horizontal line) for non-parametric data sets, unless otherwise indicated. Statistical comparison between two groups was performed using Student's unpaired t-test or Mann-Whitney test, if groups were parametric or non-parametrically distributed, respectively. If more than two parametric groups were compared, one-way ANOVA with Bonferroni post hoc test was applied, while Kruskal-Wallis test with Dunn's post hoc test was used for non-parametric groups. Results with $p<0.05$ were considered statistically significant.

\section{Results}

To investigate the role of hepcidin in $\mathrm{Fe}^{2+}$ - and $\mathrm{Cd}^{2+}$-induced oxidative stress and damage at the cellular level, we first tested different rodent cell lines derived from several nephron segments. In rat PT [WKPT-0293 Cl.2; (Woost et al. 1996)], mouse cortical collecting duct (CCD) [ $\mathrm{mCCD}(\mathrm{cl} .1)$; (Gaeggeler et al. 2005)], and mouse inner medullary collecting duct (IMCD) $\left[\mathrm{mIMCD}_{3}\right.$; (Rauchman et al. 1993)] cell lines, Hampl gene expression was measured using primer pairs common to mouse and rat Hampl (see qPCR Methods). The highest mRNA expression levels were detected in $\mathrm{mIMCD}_{3}$ cells (Suppl. Fig. 1), which aligns with hepcidin protein levels in different segments of the mammalian nephron (Kulaksiz et al. 2005).

When $\mathrm{mIMCD}_{3}$ cells were exposed to $\mathrm{Cd}^{2+}$ or $\mathrm{Fe}^{2+}$ for $24 \mathrm{~h}$, both metal ions decreased cell viability, although with different potencies. $\mathrm{Cd}^{2+}$ displayed an $E C_{50}$ of about $5 \mu \mathrm{mol} / \mathrm{l}$, whereas $\mathrm{Fe}^{2+}$ was less potent with an $E C_{50}$ of about $100 \mu \mathrm{mol} / 1$ (Fig. 1) (equimolar concentrations of $\mathrm{Fe}^{3+}$ had no effect). Interestingly, $\mathrm{Cd}^{2+}$ and $\mathrm{Fe}^{2+}$ at $E C_{50}$ concentrations increased hepcidin expression of $\mathrm{mIMCD}_{3}$ cells at both the mRNA and protein expression level, as assayed by immunofluorescence microscopy (Fig. 2), suggesting an adaptive response to metal ion stress and death. $\mathrm{Cd}^{2+}$ ( $5 \mu \mathrm{mol} / \mathrm{l}$ ) appeared to be more effective than $100 \mu \mathrm{mol} / \mathrm{l}$ $\mathrm{Fe}^{2+}$ because $\mathrm{Cd}^{2+}$ rapidly (46 h) induced hepcidin expression (Figs. 2a, 2c). In contrast, $\mathrm{Fe}^{2+}$ had no effect at $6 \mathrm{~h}$ but after $24 \mathrm{~h}$ showed a similar magnitude of induction as $\mathrm{Cd}^{2+}$ (Figs. 2b, 2d). Of note, use of ascorbate in the $\mathrm{Cd}^{2+}$ experiments (ascorbate was used to prevent oxidation to $\mathrm{Fe}^{3+}$ in the $\mathrm{Fe}^{2+}$ experiments) did not interfere with Hampl expression $(123 \pm 13 \%$ in 6 experiments, compared to respective Hampl expression with $\mathrm{Cd}^{2+}$ but without ascorbate) (data not shown).

To further clarify the role of hepcidin in cell injury induced by $\mathrm{Cd}^{2+}$ and $\mathrm{Fe}^{2+}$ in $\mathrm{mIMCD}_{3}$ cells, Hampl was effectively silenced by RNAi, as shown by complete eradication of $\mathrm{Cd}^{2+}$-induced upregulation of Hampl (Suppl. Figs 2a, 2b). Under these conditions, cell viability experiments were repeated in $\mathrm{mIMCD}_{3}$ cells. Surprisingly, Hampl silencing had opposite effects on toxicity of both metal ions after $24 \mathrm{~h}$ exposure: $\mathrm{Cd}^{2+}$ toxicity was

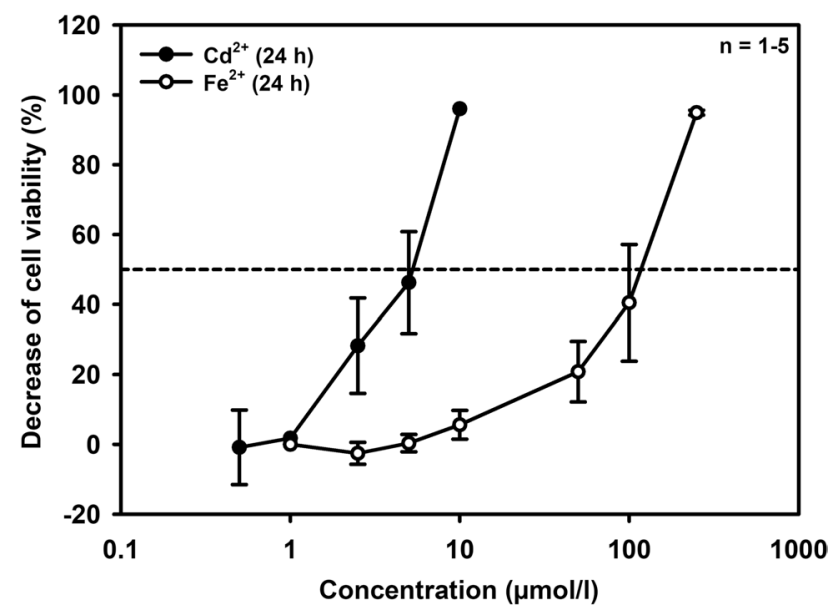

Fig. 1 Viability of mouse inner medullary collecting duct cells $\left(\mathrm{mIMCD}_{3}\right)$ exposed to different $\mathrm{Cd}^{2+}$ and $\mathrm{Fe}^{2+}$ concentrations for $24 \mathrm{~h}$. Cell viability was determined by MTT assay. Means \pm SD are shown with the exception of the highest concentration used 


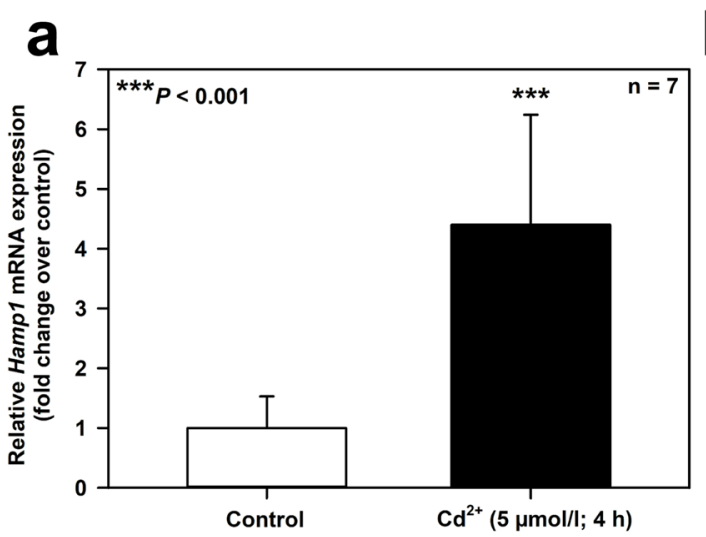

\section{b}

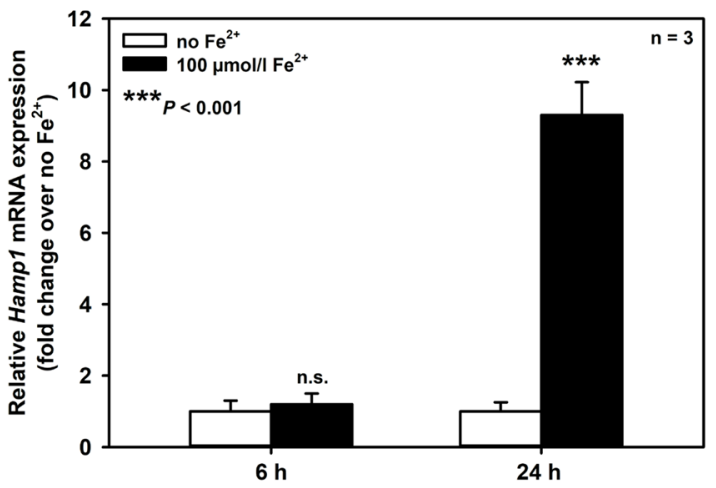

C
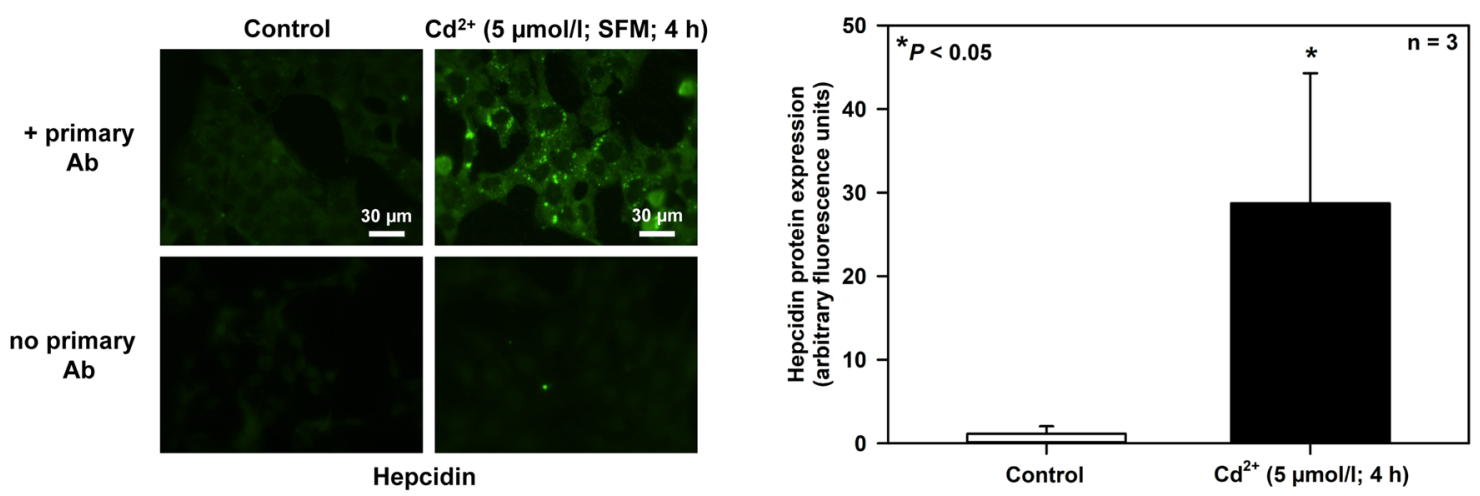

d
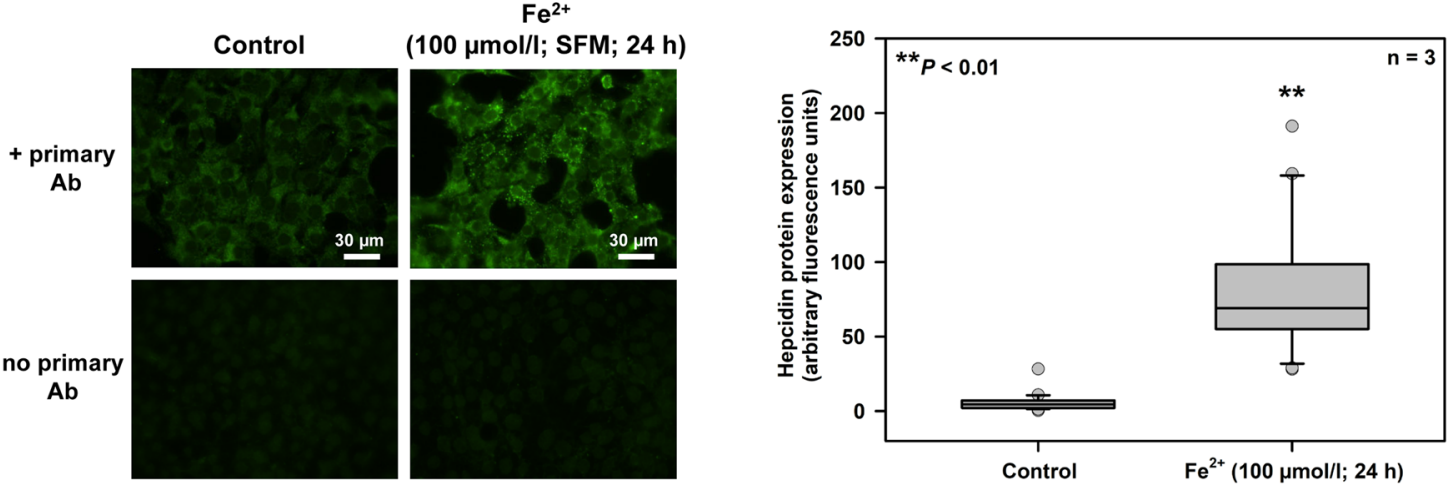

Fig. $2 \mathrm{Cd}^{2+}$ and $\mathrm{Fe}^{2+}$ increase hepcidin expression in $\mathrm{mIMCD}_{3}$ cells. Quantitative real-time PCR of Hampl transcript levels in cells exposed to $\mathrm{Cd}^{2+}$ (a) or $\mathrm{Fe}^{2+}$ (b) for different times. Means $\pm \mathrm{SD}$ are plotted. n.s. $=$ not significant. Representative immunofluorescence microscopy images of hepcidin protein expression in cells exposed to $\mathrm{Cd}^{2+}(\mathbf{c}$, left $)$ or $\mathrm{Fe}^{2+}(\mathbf{d}$, left) for different times. Immunofluorescence

data were quantified in cells exposed to $\mathrm{Cd}^{2+}$ (c, right) or $\mathrm{Fe}^{2+}$ (d, right). Means \pm SD are shown in (c) and box plots presenting 25 and 75 percentiles, median (horizontal line) and single experimental values in (d). Statistical analyses plotted compare control versus experimental conditions using unpaired Student's $t$-test $(\mathbf{a}, \mathbf{b}, \mathbf{c})$ or non-parametric Mann-Whitney-test (d)

reduced (Fig. 3a) whereas $\mathrm{Fe}^{2+}$ toxicity was exacerbated (Fig. 3b). As an endpoint of cell viability/death, the MTT assay does not discriminate between apoptosis, necrosis, or decreased proliferation. Therefore, we complemented these observations with specific tests for apoptosis and necrosis, which essentially confirmed the MTT data:

Hampl silencing decreased both apoptosis (Figs. 3c, 3d) and necrosis (Fig. 3e) induced by $\mathrm{Cd}^{2+}$, whereas it increased necrosis in $\mathrm{Fe}^{2+}$-treated $\mathrm{mIMCD}_{3}$ cells (Fig. 3e). Transfection of a Hampl plasmid in $\mathrm{mIMCD}_{3}$ cells for $24 \mathrm{~h}$ increased Hampl expression by about twofold (Suppl. Fig. 2c) and had opposite effects on viability of $\mathrm{mIMCD}_{3}$ 
Fig. 3 Opposing effects of hepcidin on cell fate of $\mathrm{mIMCD}_{3}$ cells exposed to $\mathrm{Cd}^{2+}$ or $\mathrm{Fe}^{2+}$ and protective role of iron on $\mathrm{Cd}^{2+}$-induced death. Hepcidin was either silenced by Hamp1 siRNA (a-e, g, h), or overexpressed by Hampl plasmid transfection (f), as described in the Methods. Cell viability was determined by MTT assay (a, b, f-h), apoptotic cell death by detection of single stranded (ss) DNA (c) or PARP cleavage (cPARP) (d), and necrosis by measurement of trypan blue uptake as percentage of total cell number (e). $\mathrm{Cd}^{2+}, \mathrm{Fe}^{2+}$ and/ or the iron chelator desferrioxamine (DFO) were applied for $24 \mathrm{~h}$ prior to measurement of cell viability. Means \pm SD are plotted. Statistical analyses compare either control siRNA/ plasmid versus Hamp1 siRNA/ plasmid transfections using unpaired Student's $t$-test (a-c, e, f), or assess all experimental conditions using one-way ANOVA with Bonferroni post hoc test $(\mathbf{d}, \mathbf{g}, \mathbf{h})$. n.s. $=$ not significant

a

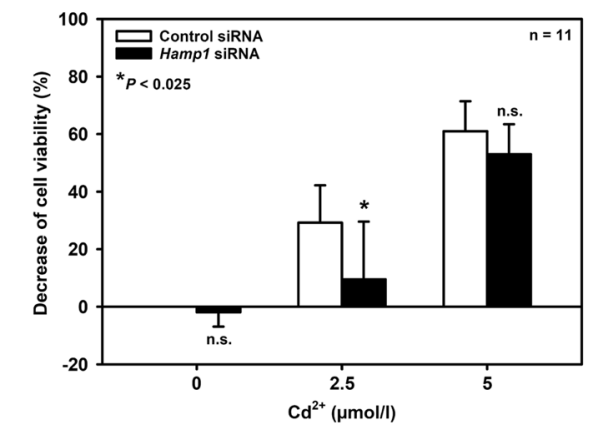

b
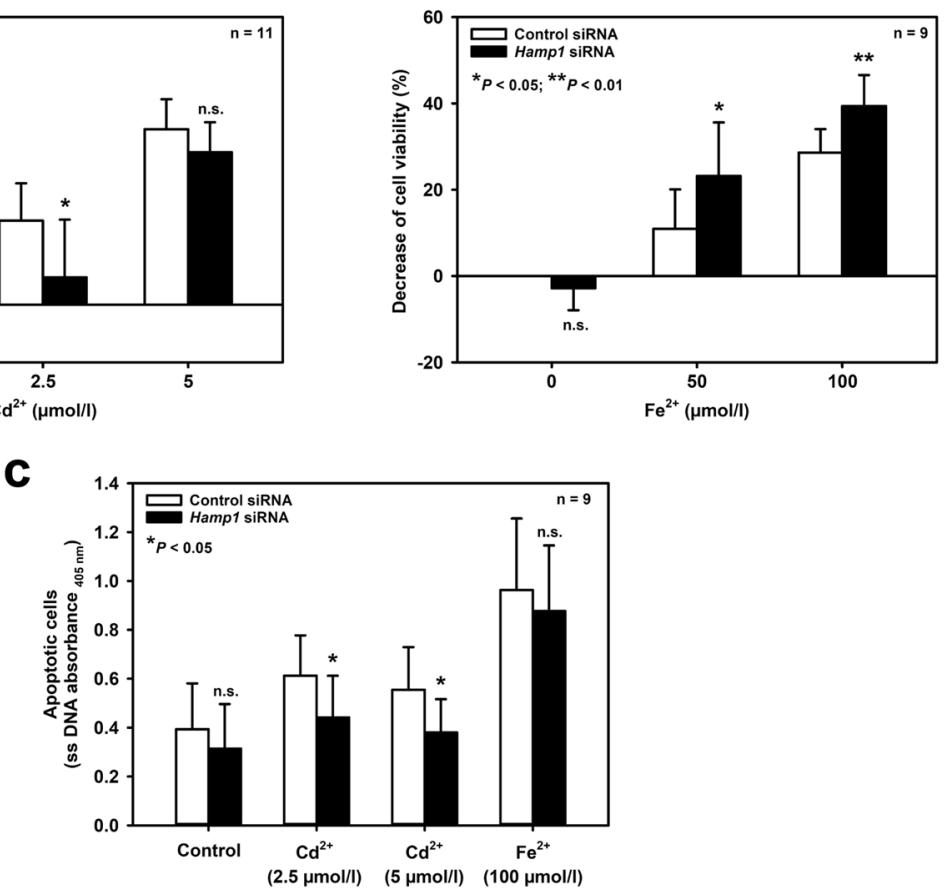

d
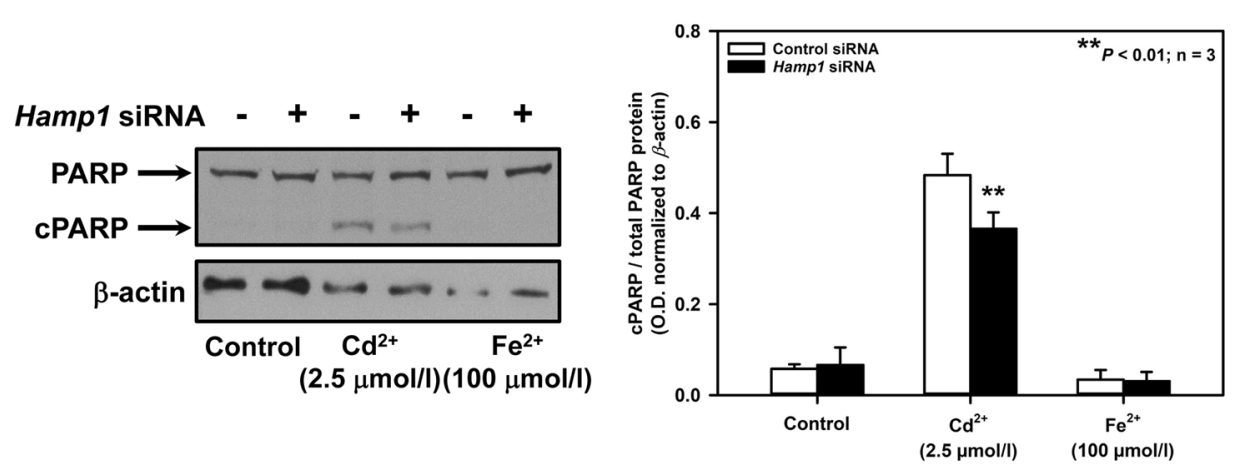

e

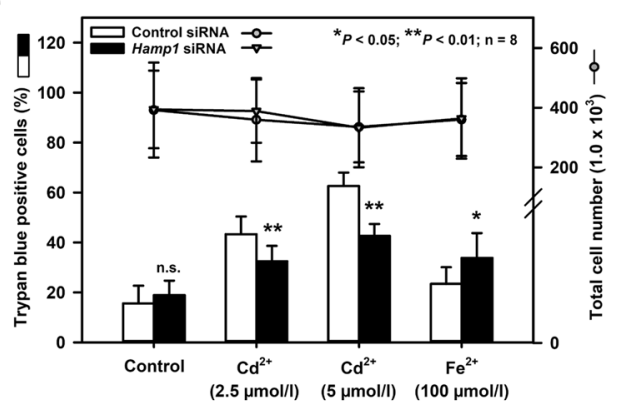

cells exposed to $\mathrm{Cd}^{2+}$ or $\mathrm{Fe}^{2+}$, when compared to Hampl silencing (see Figs. 3a, 3b): Hepcidin overexpression further increased $\mathrm{Cd}^{2+}$-induced but reduced $\mathrm{Fe}^{2+}$-induced cell death (Fig. 3f).

Hepcidin is protective against kidney cell injury associated with increased formation of ROS (Scindia et al. 2015; van Swelm et al. 2018). Furthermore, both $\mathrm{Cd}^{2+}$ and $\mathrm{Fe}^{2+}$ damage cells by inducing oxidative stress (reviewed in Cuypers et al. 2010; Dixon and Stockwell 2014). Hence, the role of hepcidin in oxidative stress elicited by $\mathrm{Cd}^{2+}$ and $\mathrm{Fe}^{2+}$ in $\mathrm{mIMCD}_{3}$ cells was investigated. As shown in Fig. 4a, both $\mathrm{Cd}^{2+}(2.5 \mu \mathrm{mol} / \mathrm{l})$ and $\mathrm{Fe}^{2+}(50 \mu \mathrm{mol} / \mathrm{l})$ increased ROS formation to a similar extent after $24 \mathrm{~h}$ exposure, as detected with CellROX ${ }^{\mathrm{TM}}$ Green. However, 
Fig. 3 (continued)

Fig. 4 Diverging effects of hepcidin on ROS formation induced by $\mathrm{Cd}^{2+}$ and $\mathrm{Fe}^{2+}$ and protective role of iron on $\mathrm{Cd}^{2+}$-induced oxidative stress in $\mathrm{mIMCD}_{3}$ cells. Hepcidin was either silenced by Hampl siRNA (a, c, d) or overexpressed by Hampl plasmid transfection (b), as described in the Methods. ROS formation was assayed with a fluorimetric kit. $\mathrm{Cd}^{2+}, \mathrm{Fe}^{2+}$ and/ or the iron chelator desferrioxamine (DFO) were applied for $24 \mathrm{~h}$ prior to measurement of ROS formation. Means \pm SD are plotted. Statistical analyses compare either control siRNA/ plasmid versus Hampl siRNA/ plasmid transfections using unpaired Student's $t$-test (a, b), or evaluate all experimental conditions using one-way ANOVA with Bonferroni posthoc test $(\mathbf{c}, \mathbf{d})$

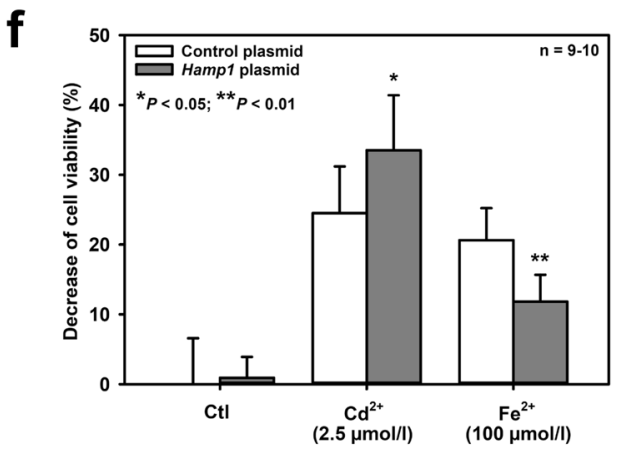

g

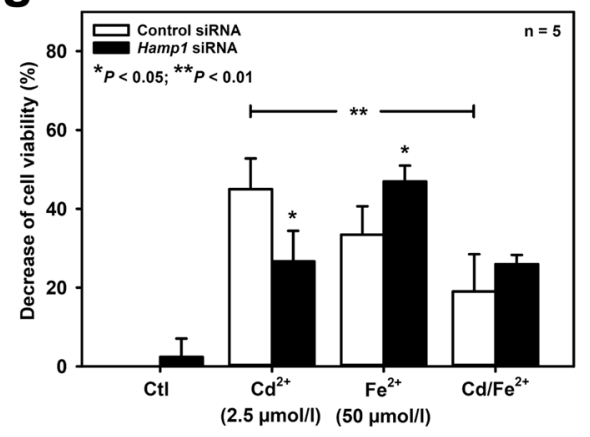

h

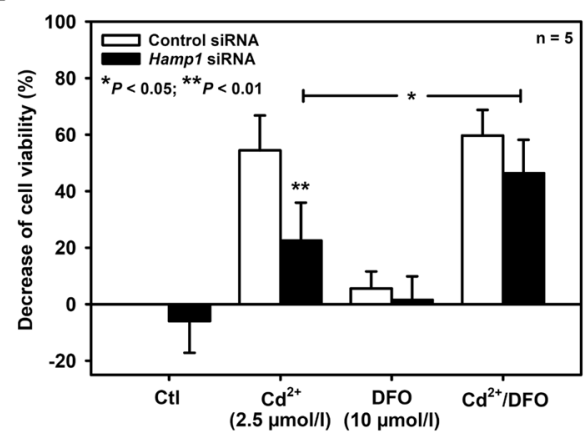

a

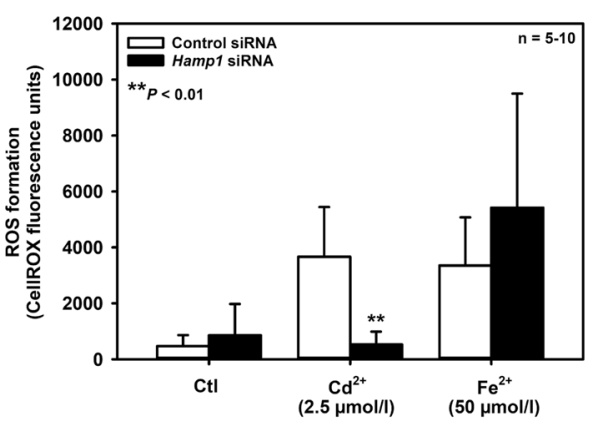

C

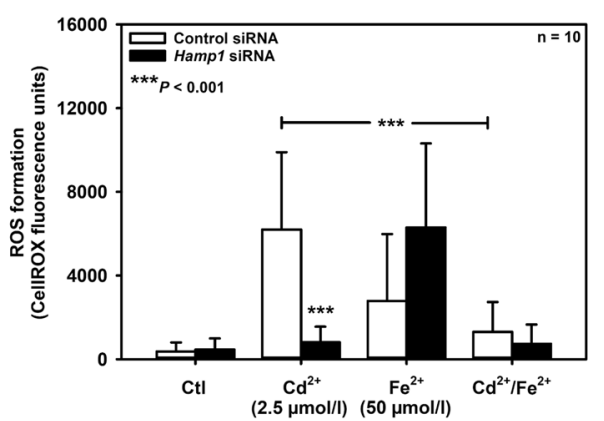

b

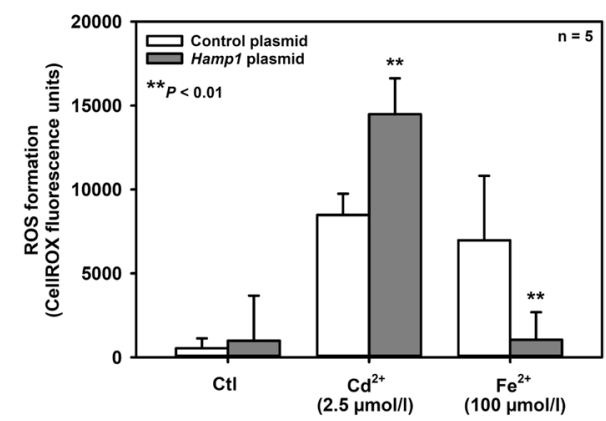

d

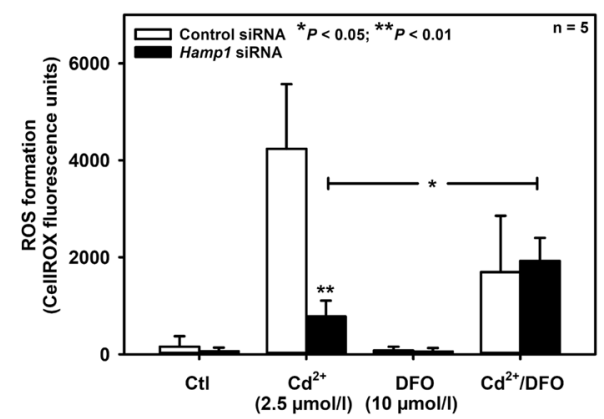

Hampl silencing decreased ROS production induced by $\mathrm{Cd}^{2+}$ whereas it increased ROS with $\mathrm{Fe}^{2+}$ exposure. Overexpressing hepcidin in $\mathrm{mIMCD}_{3}$ cells augmented $\mathrm{Cd}^{2+}$ but abolished $\mathrm{Fe}^{2+}$-induced ROS formation (Fig. 4b). ROS measurements mirrored MTT cell viability data (Fig. 3), indicating that $\mathrm{Cd}^{2+}$ - and $\mathrm{Fe}^{2+}$-induced oxidative stress mediates cell death in mIMCD $_{3}$ cells. Yet hepcidin had opposite effects on $\mathrm{Cd}^{2+}$ - and $\mathrm{Fe}^{2+}$-induced ROS formation and consequent cell death, namely protection against 
$\mathrm{Fe}^{2+}$ but aggravation of $\mathrm{Cd}^{2+}$-mediated oxidative stress and death.

Hepcidin can chelate endogenous metal ions, in particular $\mathrm{Fe}^{2+}$ (Abbas et al. 2018; Farnaud et al. 2006, 2008; Gerardi et al. 2005). If so, the expression level of cellular hepcidin should determine the levels of endogenous redox active iron. This would explain the protective effects of hepcidin overexpression (Figs. 3f, 4b), and increased damage and ROS formation by Hampl silencing (Figs. 3b, 3e, 4a) in $\mathrm{Fe}^{2+}$-exposed cells. In contrast, opposite results obtained in $\mathrm{Cd}^{2+}$-exposed cells (Figs. 3a, 3c-f, 4a, 4b) make it unlikely that hepcidin also chelates $\mathrm{Cd}^{2+}$ in a similar manner to $\mathrm{Fe}^{2+}$. $\mathrm{Cd}^{2+}$ damages proteins and cells by competing with and displacing $\mathrm{Fe}^{2+}$ from various binding sites (reviewed in Moulis 2010). We therefore hypothesized that increased endogenous $\mathrm{Fe}^{2+}$ in Hampl-silenced cells prevents its displacement by $\mathrm{Cd}^{2+}$ and cell injury (Figs. 3a, 3c-e). Conversely, decreased endogenous $\mathrm{Fe}^{2+}$ by hepcidin overexpression promotes $\mathrm{Cd}^{2+}$ displacement and cell damage (Fig. 3f).

To test this concept, the effect of exogenously added $\mathrm{Fe}^{2+}$ $(50 \mu \mathrm{mol} / \mathrm{l})$ was investigated on viability of control and Hampl-silenced $\mathrm{mIMCD}_{3}$ cells exposed to $\mathrm{Cd}^{2+}(2.5 \mu \mathrm{mol} / \mathrm{l}$, $24 \mathrm{~h})$. Addition of $\mathrm{Fe}^{2+}$ increased cell viability of $\mathrm{Cd}^{2+}$ exposed cells transfected with control siRNA, but had no additional effect in Hamp1-silenced cells (Fig. 3g), suggesting a cellular mechanism protecting against $\mathrm{Cd}^{2+}$ toxicity that needs iron. We then performed the opposite experiment by depleting chelatable endogenous cellular iron with the iron chelator desferrioxamine (DFO) (Keberle 1964), which does not bind $\mathrm{Cd}^{2+}$ (Harrington et al. 2012). DFO $(10 \mu \mathrm{mol} / \mathrm{l})$ abolished the protective effect of Hampl silencing on $\mathrm{Cd}^{2+}$ damage (Fig. 3h), indicating that increased endogenous chelatable iron protects against $\mathrm{Cd}^{2+}$ damage in Hampl-deficient cells. ROS formation induced by $\mathrm{Cd}^{2+}$ was also measured under conditions of exposure to exogenously added $\mathrm{Fe}^{2+}$ or DFO: addition of $\mathrm{Fe}^{2+}(50 \mu \mathrm{mol} / \mathrm{l})$ decreased $\mathrm{Cd}^{2+}$-induced ROS formation in control cells, with no further effect by Hampl silencing (Fig. 4c). With DFO, Hampl-silenced cells showed a significant increase of $\mathrm{Cd}^{2+}$-induced ROS formation, when compared to the respective controls without DFO (Fig. 4d).

ROS metabolizing enzymes require metal ions as co-factors for their activity. In contrast to superoxide dismutases and glutathione peroxidases, which are not iron-dependent (Halliwell and Gutteridge 2015), catalases are iron-dependent enzymes (Deisseroth and Dounce 1970) that convert hydrogen peroxide $\left(\mathrm{H}_{2} \mathrm{O}_{2}\right)$ into oxygen and water (Ratliff et al. 2016). Strikingly, their activity is increased or reduced by high or low cellular iron, respectively (Deisseroth and Dounce 1970; Macdougall 1972; Schultze and Kuiken 1941; Srigiridhar and Nair 1998), and disrupted by $\mathrm{Cd}^{2+}$, which results in increased ROS formation with $\mathrm{Cd}^{2+}$ (reviewed in Cuypers et al. 2010). Deep sequencing of micro-dissected nephron segments from rodent kidney demonstrated catalase mRNA (Cat) is mainly detected in the S1-S3 segments of the PT, but significant levels of catalase can be detected in other nephron segments as well. In the $\mathrm{CD}$, the highest expression was measured in the IMCD, although PT expression was about sixfold higher than in the IMCD (Lee et al. 2015). Expression of Cat mRNA by qPCR was $\sim 2.5$-fold higher in WKPT-0293 Cl.2 than in $\mathrm{mIMCD}_{3}$ cells (Suppl. Table 2), which was confirmed at the protein level by immunoblotting. The expression of catalase protein by immunofluorescence staining of mouse kidney sections (Suppl. Fig. 3a) as well as by immunoblotting of crudely separated mouse kidney cortex and medulla (Suppl. Fig. 3b) confirmed published differential expression measured in rodent cortical and medullar nephron segments at the mRNA (Lee et al. 2015) and protein levels (Muse et al. 1994). Moreover, catalase activity in rodent kidney cortex and medulla (Gonzalez-Flecha et al. 1993) correlated with mRNA expression levels [see above; (Lee et al. 2015)] and matched catalase activity in PT WKPT-0293 Cl.2 cells, which was approximately fourfold higher than in $\mathrm{mIMCD}_{3}$ cells (Suppl. Table 2).

The effect of $\mathrm{Cd}^{2+}$ on catalase function and the impact of exogenously added $\mathrm{Fe}^{2+}$ or DFO were investigated in mIMCD 3 cells with or without Hampl silencing. As shown in Suppl. Fig. 4, except for $\mathrm{Fe}^{2+}$ increasing Cat mRNA, none of the experimental manipulations performed in this study significantly affected $\mathrm{Cat}$ mRNA expression. Yet exposure of cells to $\mathrm{Cd}^{2+}$ for $24 \mathrm{~h}$ strongly decreased catalase activity, whereas $\mathrm{Fe}^{2+}$ enhanced catalase activity (Fig. 5a), which confirms recent observations in plants (Biyani et al. 2019). The latter may be partly accounted for by the induction of Cat gene expression by $\mathrm{Fe}^{2+}$ (see Suppl. Fig. 4 and Piloni et al. 2016). Co-exposure with $\mathrm{Fe}^{2+}$ prevented the reduction of catalase activity induced by $\mathrm{Cd}^{2+}$. And Hampl silencing had the same protective effect as addition of $\mathrm{Fe}^{2+}$ (although neither Hampl silencing nor overexpression affected Cat mRNA levels; see Suppl. Fig. 4) on $\mathrm{Cd}^{2+}$-induced inhibition of catalase activity (Fig. 5a). DFO prevented the rescue of catalase activity by Hampl silencing in $\mathrm{Cd}^{2+}$-treated cells (Fig. 5b), which once more supports the concept that hepcidin binds iron (Farnaud et al. 2006, 2008; Gerardi et al. 2005).

Hepcidin is also detected in the cortical collecting duct (Gaeggeler et al. 2005), though at a lower level (Kulaksiz et al. 2005) (see also Suppl. Fig. 1). To ascertain whether reduced levels of hepcidin also interfere with endogenous redox active ion levels, key experiments were executed in a model system, namely the $\mathrm{mCCD}(\mathrm{cl} .1)$ cell line, derived from mouse cortical collecting duct (see Suppl. Fig. 1). As shown in Fig. $6 \mathrm{a}, \mathrm{Cd}^{2+}$ or $\mathrm{Fe}^{2+}$ for $24 \mathrm{~h}$ decreased cell viability in a concentration-dependent manner. $\mathrm{Cd}^{2+}$ was about ten times more toxic in $\mathrm{mCCD}(\mathrm{cl} .1)$ cells $\left(E C_{50} \sim 0.5 \mu \mathrm{mol} / \mathrm{l}\right)$ than in $\mathrm{mIMCD}_{3}$ cells, whereas $\mathrm{Fe}^{2+}$ displayed similar 


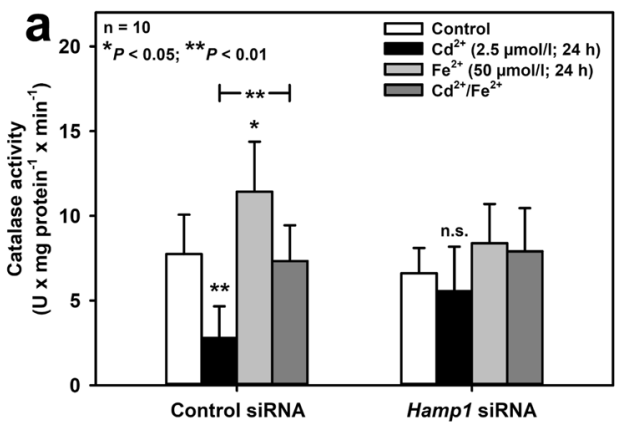

Fig. 5 Opposite effects of hepcidin silencing on catalase activity of mIMCD 3 cells exposed to $\mathrm{Cd}^{2+}$ or $\mathrm{Fe}^{2+}$ and protective role of iron on $\mathrm{Cd}^{2+}$-induced catalase dysfunction. Cells were incubated with divalent metal ions or DFO for $24 \mathrm{~h}$ prior to measuring catalase activity with a fluorometric assay. The effects of $\mathrm{Fe}^{2+}$ (a) or of the iron chela-

toxicity in both cell lines $\left(E C_{50}\right.$ of about $\left.100 \mu \mathrm{mol} / \mathrm{l}\right)$ (see Fig. 1). $\mathrm{Cd}^{2+}$ and $\mathrm{Fe}^{2+}$ at $E C_{50}$ concentrations increased hepcidin mRNA and protein expression in $\mathrm{mCCD}(\mathrm{cl} .1)$ cells, which was prevented by transient transfection with Hampl siRNA (Fig. 6b-d and data not shown). Hepcidin silencing or co-exposure with $\mathrm{Fe}^{2+}$ reduced $\mathrm{Cd}^{2+}$, but not $\mathrm{Fe}^{2+}$ toxicity (Fig. 6e). These data further supported the hypothesis that hepcidin chelates protective $\mathrm{Fe}^{2+}$ in $\mathrm{mCCD}$ (cl.1) cells and that $\mathrm{Fe}^{2+}$ or Hampl silencing rescue catalase dysfunction elicited by $\mathrm{Cd}^{2+}$, which was confirmed by the experiments shown in Fig. 6f. This further underlines the validity of the model shown in Fig. 7 for all nephron segments (and possibly other tissues) expressing hepcidin.

\section{Discussion}

In the present study, we demonstrate distinct effects of hepcidin on $\mathrm{Fe}^{2+}$ - and $\mathrm{Cd}^{2+}$-induced oxidative stress and death in $\mathrm{mIMCD}_{3}$ and $\mathrm{mCCD}(\mathrm{cl} .1)$ cells (Fig. 7). Hepcidin protects against $\mathrm{Fe}^{2+}$-mediated oxidative cell injury but aggravates $\mathrm{Cd}^{2+}$-induced ROS formation and death (Figs. 3, 4).

$\mathrm{Cd}^{2+}$ is about 20-200 times more potent than $\mathrm{Fe}^{2+}$ to induce cell injury (Figs. 1, 3, 6a, 6e), ROS formation (Fig. 4), and hepcidin upregulation (Figs. 2, 6b-d) in $\mathrm{mIMCD}_{3}$ and $\mathrm{mCCD}(\mathrm{cl} .1)$ cells. The different damaging potency of $\mathrm{Cd}^{2+}$ and $\mathrm{Fe}^{2+}$ could be explained by differences in the permeability of both metal ions in these cells as well as competition between $\mathrm{Cd}^{2+}$ and $\mathrm{Fe}^{2+}$ for uptake pathways in experiments where $\mathrm{Cd}^{2+}$ and $\mathrm{Fe}^{2+}$ were co-exposed. Two transport pathways that carry both $\mathrm{Cd}^{2+}$ and $\mathrm{Fe}^{2+}$ are expressed in rodent $\mathrm{CD}$, namely DMT1 and the voltage-gated calcium channel $\mathrm{Ca}_{\mathrm{V}} 3.1\left(\alpha_{1} \mathrm{G}\right)$ (Andreasen et al. 2000; Ferguson et al. 2001; Wareing et al. 2003) (reviewed in Thévenod and Wolff 2016). The localization of these proteins was investigated in $\mathrm{mIMCD}_{3}$ cells in which most experiments in this study

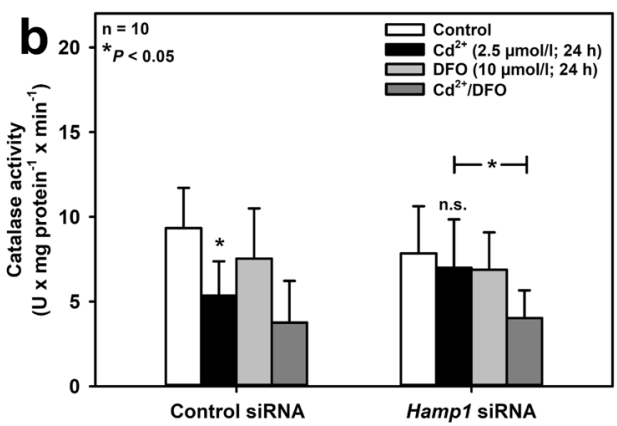

tor desferrioxamine (DFO) (b) on catalase activity were determined in the absence or presence of $\mathrm{Cd}^{2+}$ in control or Hampl-silenced cells. Means \pm SD are shown. Statistical analysis evaluates all experimental conditions with each other using one-way ANOVA with Bonferroni post-hoc test. n.s. $=$ not significant

were performed. DMT1 was not detected among $\mathrm{mIMCD}_{3}$ surface proteins, as determined by surface biotinylation and immunoblotting (Suppl. Fig. 5a), thus excluding DMT1 as a relevant uptake pathway for $\mathrm{Cd}^{2+}$ and $\mathrm{Fe}^{2+}$. In contrast, the calcium channel $\mathrm{Ca}_{\mathrm{v}} 3.1$ was expressed in $\mathrm{mIMCD}_{3}$ cells by immunofluorescence microscopy (Suppl. Fig. 5b, left) and mainly observed at the cell periphery, suggesting localization in the plasma membrane, which was confirmed by laser scanning confocal microscopy (Suppl. Fig. 5b, right) and surface biotinylation experiments (Suppl. Fig. 5c, arrow). $\mathrm{Ca}_{\mathrm{v}} 3.1$ shows a lower permeability for $\mathrm{Fe}^{2+}$ compared to $\mathrm{Cd}^{2+}$ (Lopin et al. 2012a, b), which could well explain the higher potency of $\mathrm{Cd}^{2+}$ compared to $\mathrm{Fe}^{2+}$ (Figs. 1, 6a), but cannot be the reason for $\mathrm{Cd}^{2+}$ and $\mathrm{Fe}^{2+}$ co-exposure almost abolishing comparable levels of $\mathrm{Cd}^{2+}$ or $\mathrm{Fe}^{2+}$ toxicity and oxidative stress (Figs. 3g, 4c, 6e).

The protein MT is upregulated by $\mathrm{Cd}^{2+}$ in the kidney (Sabolic et al. 2010) and protects against $\mathrm{Cd}^{2+}$ toxicity by its strong $\mathrm{Cd}^{2+}$ chelating (Freisinger and Vasak 2013) and anti-oxidative properties (Ruttkay-Nedecky et al. 2013), but it lacks iron binding properties (Waalkes et al. 1984). To exclude the possibility that Hampl silencing as well as increased or decreased endogenous iron might have altered the expression of MT, which would explain some of the observed $\mathrm{Cd}^{2+}$-induced changes of cell viability and ROS formation under those experimental conditions, immunofluorescence staining of endogenous MT was performed in $\mathrm{mIMCD}_{3}$ cells. Basal MT expression was low in $\mathrm{mIMCD}_{3}$ cells, while it increased by 5.5-8.3-fold (means of six experiments) upon exposure to $2.5 \mu \mathrm{mol} / 1 \mathrm{Cd}^{2+}$ for $24 \mathrm{~h}$ (Suppl. Fig. 6). In contrast, Hampl silencing, $\mathrm{Fe}^{2+}(50 \mu \mathrm{mol} / \mathrm{l})$ or DFO $(10 \mu \mathrm{mol} / \mathrm{l})$ did not have any effect on MT expression (Suppl. Fig. 6). Hence, MT expression does not contribute to the observed effects of these experimental manipulations.

Several protective roles have been attributed to local (renal) hepcidin in the context of metal ion toxicity. 
Fig. $6 \mathrm{Cd}^{2+}$ and $\mathrm{Fe}^{2+}$ increase hepcidin expression, which sensitizes mouse cortical collecting duct cells to $\mathrm{Cd}^{2+}$-induced death and catalase dysfunction whereas co-exposure with $\mathrm{Fe}^{2+}$ or Hamp1 silencing protect against $\mathrm{Cd}^{2+}$-induced damage. (a) Viability of $\mathrm{mCCD}(\mathrm{cl} .1)$ cells exposed to various $\mathrm{Cd}^{2+}$ and $\mathrm{Fe}^{2+}$ concentrations by MTT assay. (b) Representative immunofluorescence microscopy images of hepcidin protein in cells exposed to $\mathrm{Cd}^{2+}$ or $\mathrm{Fe}^{2+}$ (left) and quantification of immunofluorescence data (right). Statistical analysis compares control versus experimental conditions using unpaired Student's $t$-test. (c, d) Efficient hepcidin silencing with Hampl siRNA. $\mathrm{Cd}^{2+}$ upregulation of hepcidin protein by immunofluorescence microscopy (c), or $\mathrm{Fe}^{2+}$-mediated induction of Hamp1 mrNA by quantitative real-time PCR (d) were abolished by transient transfection of Hamp1 siRNA. Satistical analyses compare controls versus metal ion-treated cells using unpaired Student's $t$-test. (e, f) Effects of $\mathrm{Fe}^{2+}$ and/or hepcidin silencing with Hamp1 siRNA on cell viability (e) or catalase activity (f) measured in the absence or presence of $\mathrm{Cd}^{2+}$. Viability was measured by MTT assay and catalase activity with a fluorimetric assay. Statistical analysis evaluates all experimental conditions with each other using one-way ANOVA with Bonferroni post-hoc test. n.s. $=$ not significant a
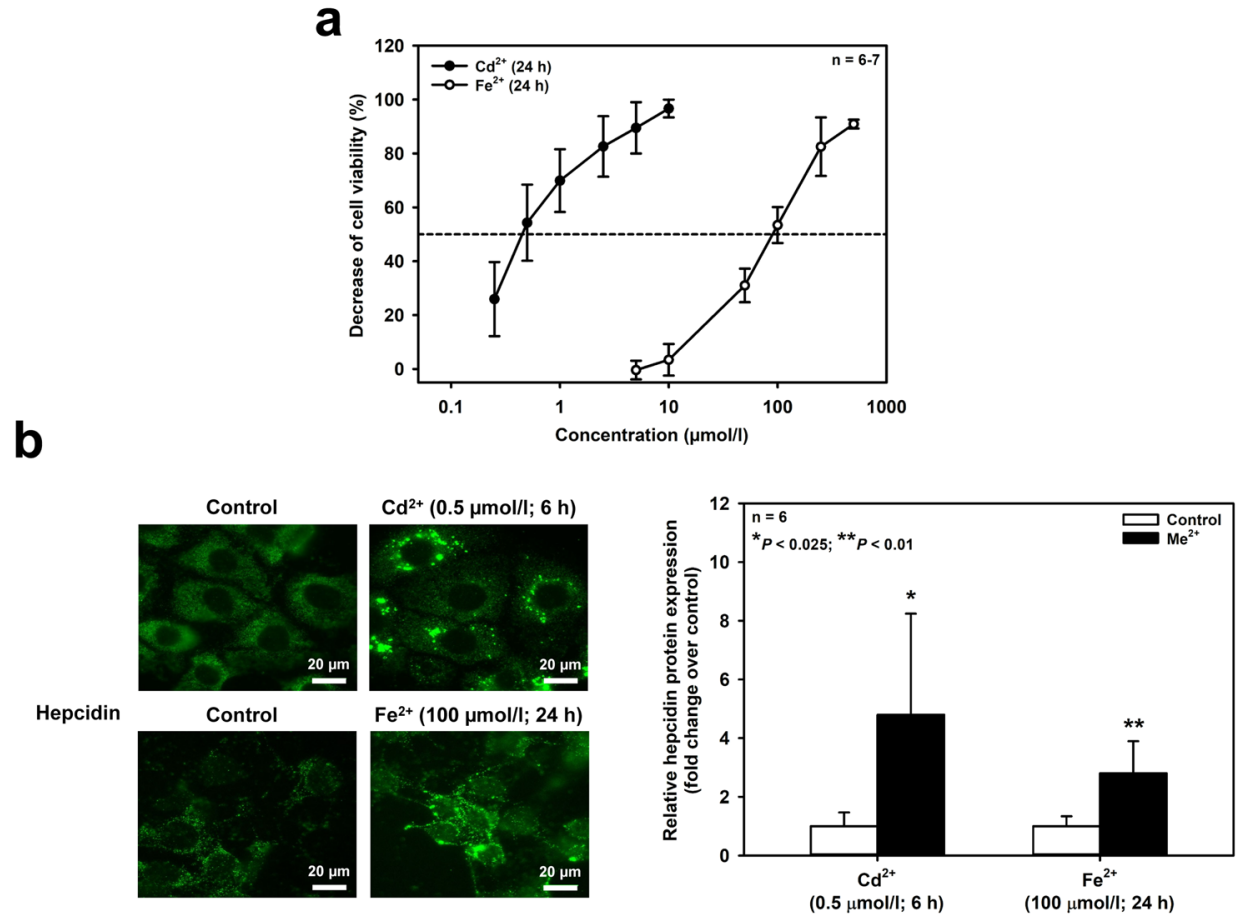

C

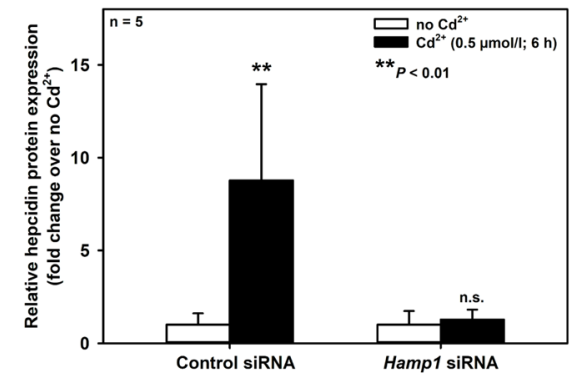

d

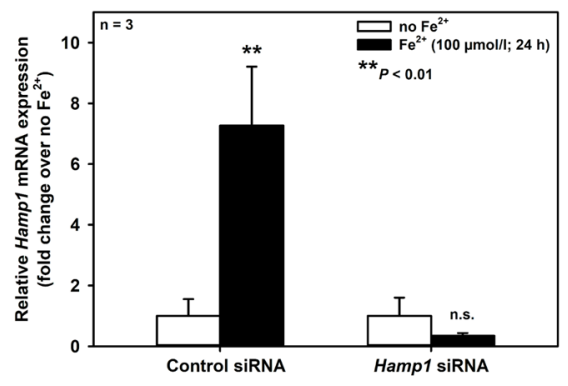

e

f

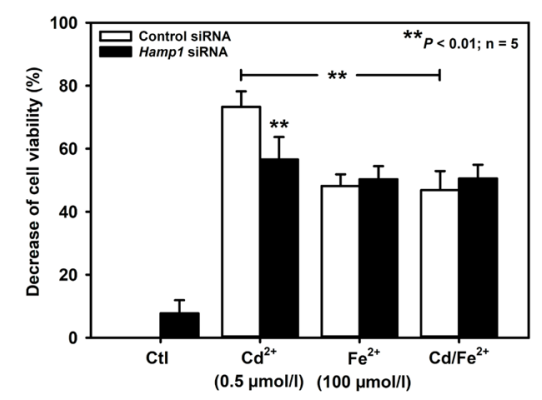

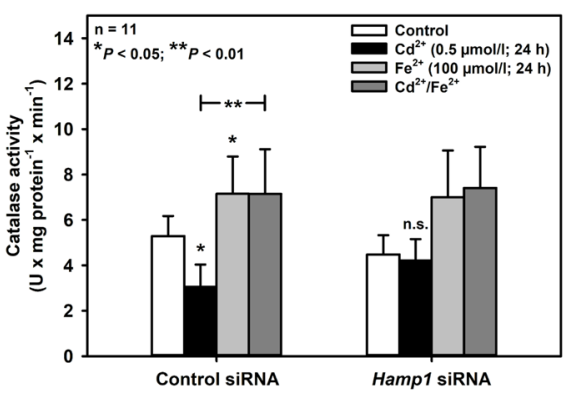

Hepcidin protects against cell death induced by hemoglobin (van Swelm et al. 2016, 2018), reduces oxidative stress in murine ischemia/reperfusion acute kidney injury (Scindia et al. 2015), or chelates endogenous metal ions, including $\mathrm{Fe}^{2+}$ and copper (Abbas et al. 2018; Farnaud et al. 2006, 2008; Gerardi et al. 2005). All three mechanisms are consistent with the $\mathrm{Fe}^{2+}$, but not $\mathrm{Cd}^{2+}$, effects described in this study (see Figs. 3-6). However, both $\mathrm{Fe}^{2+}$ and $\mathrm{Cd}^{2+}$ damage
mIMCD $_{3}$ cells by oxidative stress (Figs. 3, 4). To reconcile these seemingly disparate results, we hypothesized that endogenous iron levels are crucial for catalase function and $\mathrm{Cd}^{2+}$ damages catalase by displacement of iron (Moulis 2010). As heme-containing enzymes, catalases require iron for their activity (Deisseroth and Dounce 1970), and iron deficiency decreases their activity in various tissues, including the kidney (Macdougall 1972; Schultze and Kuiken 


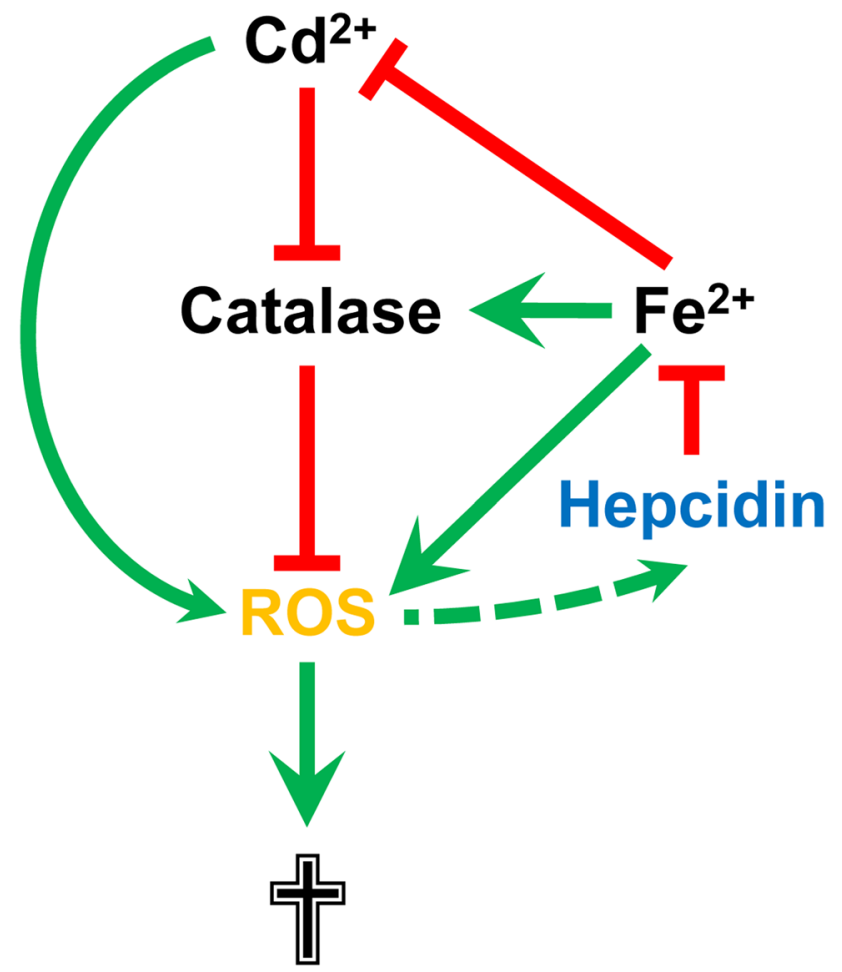

Fig. 7 Model of the influence of hepcidin, $\mathrm{Cd}^{2+}$ and $\mathrm{Fe}^{2+}$ on ROS formation, catalase activity and cell death in renal collecting duct cells. Both $\mathrm{Cd}^{2+}$ and $\mathrm{Fe}^{2+}$ increase formation of reactive oxygen species (ROS) in renal collecting duct (CD) cells and iron-dependent catalase degrades ROS. ROS cause cell death but also induce upregulation of hepcidin, which chelates $\mathrm{Fe}^{2+}$, but not $\mathrm{Cd}^{2+} . \mathrm{Cd}^{2+}$ inactivates catalase by displacing iron from catalase. $\mathrm{Fe}^{2+}$ reduces $\mathrm{Cd}^{2+}$-induced catalase inactivation, while hepcidin upregulation protects $\mathrm{CD}$ cells against $\mathrm{Fe}^{2+}$-induced oxidative stress, but sensitizes them to $\mathrm{Cd}^{2+}$-induced catalase dysfunction, ROS formation and death. For further details, see main text. Green arrows indicate stimulatory, red arrows inhibitory effects. Solid lines represent experimental evidence from the study, dotted lines evidence from the literature

1941; Srigiridhar and Nair 1998). Hepcidin upregulation increases binding of cellular iron (Farnaud et al. 2006, 2008; Gerardi et al. 2005), thus reducing the redox active labile iron pool (LIP) (Kakhlon and Cabantchik 2002) and cell stress induced by $\mathrm{Fe}^{2+}$ overload (Figs. 3f, 4b), but enhances $\mathrm{Cd}^{2+}$ toxicity by chelating endogenous iron that is required for the function of catalase (see Figs. 5, 6f).

Obviously, hepcidin appears to have no singular role in the cell (see above). Moreover, scavenging of ROS seems unlikely as a protective mechanism of hepcidin because ROS formation is increased by $\mathrm{Cd}^{2+}$ in $\mathrm{mIMCD}_{3}$ cells despite hepcidin upregulation (Fig. 2) and $\mathrm{Cd}^{2+}$-induced ROS formation is decreased by Hampl silencing (Fig. 4). Further, both systemic production of hepcidin as a liver hormone as well as tissue-specific expression as a local regulatory factor need to be considered to understand the manifold functions of hepcidin. In the kidney, hepcidin is not expressed in the
PT but exclusively found in the distal nephron (Kulaksiz et al. 2005). There it appears to protect against iron overload by controlling luminal iron uptake via DMT1 downregulation, possibly involving an autocrine mechanism (Moulouel et al. 2013). Here we demonstrate an additional protective effect of intracellular hepcidin against iron overload in distal nephron cells. Hepcidin reduces ROS formation (Fig. 4) and cell death (Figs. 3, 6), likely through its role as an iron scavenger (Farnaud et al. 2006, 2008; Gerardi et al. 2005) thus decreasing cellular levels of the redox active LIP (Kakhlon and Cabantchik 2002). Hepcidin upregulation by $\mathrm{Fe}^{2+}$ (Figs. 2, 6b, 6d) could be an additional mechanism of protection of the distal nephron against iron damage; $\mathrm{H}_{2} \mathrm{O}_{2}$ is known to upregulate hepcidin in hepatocytes (Millonig et al. 2012), which could be the underlying mechanism accounting for hepcidin induction by $\mathrm{Cd}^{2+}$ and $\mathrm{Fe}^{2+}$. Systemic iron overload pathology mainly targets the PT in experimental animals (Richter 1980; Zainal et al. 1999) and humans (Landing et al. 1989; Pardo-Mindan et al. 1990) because the PT represents the preferential site of iron uptake, as it possesses the perfect machinery required for transepithelial iron reabsorption in the kidney (reviewed in Thévenod and Wolff 2016). Hence, lack of hepcidin expression in the PT (Kulaksiz et al. 2005) may be detrimental under conditions of increased PT iron reabsorption whereas catalase upregulation induced by iron (see Suppl. Fig. 4) would be protective, at least transiently.

Chronic $\mathrm{Cd}^{2+}$ exposure leads to accumulation of $\mathrm{Cd}^{2+}$ in various organs, in particular the kidney PT, because of the presence of major luminal uptake pathways for $\mathrm{Cd}^{2+}$ along with limited routes of basolateral exit and subsequent damage (reviewed in Prozialeck and Edwards 2012; Thévenod and Wolff 2016). MT is the major protective mechanism against $\mathrm{Cd}^{2+}$ toxicity in the PT and other tissues (reviewed in Klaassen et al. 2009). In addition, catalase is highly expressed in the PT (Lee et al. 2015; Muse et al. 1994), mainly in peroxisomes, but also in the cytosol (Kalmbach and Fahimi 1978; Litwin et al. 1988). Hence, disruption of PT catalase activity by both low iron and/or increased $\mathrm{Cd}^{2+}$ will favor dysfunction of the PT, but also the distal nephron, as shown in this study for $\mathrm{mIMCD}_{3}$ cells and $\mathrm{mCCD}(\mathrm{cl} .1)$ cells. Interestingly, catalase activity in the three cell lines originating from different nephron segments [WKPT0293 Cl.2 > mIMCD $\left._{3}>\operatorname{mCCD}(\mathrm{cl} .1)\right]$ (see Suppl. Table 1) appears to inversely correlate with $\mathrm{Cd}^{2+}$ toxicity [WKPT$0293 \mathrm{Cl} .2<\mathrm{mIMCD}_{3}<\mathrm{mCCD}(\mathrm{cl} .1)$ ] (see Figs. 1, 6a and Nair et al. 2015). This is not the case for $\mathrm{Fe}^{2+}$ toxicity (see Figs. 1, 6a), suggesting that catalase activity is an important contributor to protection against $\mathrm{Cd}^{2+}$-induced damage of the kidney.

The absence of hepcidin in the PT could further protect against $\mathrm{Cd}^{2+}$ toxicity, as shown in Hampl-silenced $\mathrm{mIMCD}_{3}$ cells and $\mathrm{mCCD}(\mathrm{cl} .1)$ cells (Figs. 3a, 3c-e, 6e). 
$\mathrm{Cd}^{2+}$ also accumulates in the distal nephron (Nagamine et al. 2007; Torra et al. 1994; Wang et al. 2009; Yoshida et al. 1998). The lower catalase (Lee et al. 2015; Muse et al. 1994) and higher hepcidin expression levels (Kulaksiz et al. 2005) (which may be further upregulated by $\mathrm{Cd}^{2+}$; see Figs. 2a-c, 6b, 6c) enhance $\mathrm{Cd}^{2+}$-induced ROS formation and hence $\mathrm{Cd}^{2+}$ toxicity (see Figs. 3f, 4b). Why then is $\mathrm{Cd}^{2+}$ nephrotoxicity less pronounced in the medullary distal nephron (Johri et al. 2010)? Cellular $\mathrm{Cd}^{2+}$ entry pathways [i.e., entry pathways for essential metal ions, such as $\mathrm{Fe}^{2+}, \mathrm{Zn}^{2+}, \mathrm{Mn}^{2+}, \mathrm{Ca}^{2+}$ and their complexes with proteins or peptides; reviewed in (Thévenod et al. 2019)] are comparable between kidney cortex and medulla. The relative resistance of the distal nephron to $\mathrm{Cd}^{2+}$ toxicity may result from its lower sensitivity to oxidative stress (Campos et al. 1993; Gonzalez-Flecha et al. 1993). Thus increased adaptive responses by oxidative and other stressinduced processes must underlie less prominent $\mathrm{Cd}^{2+}$ toxicity in the distal nephron (Johri et al. 2010), Consequently, the distal nephron displays an increased potential for adaptive responses by oxidative stress-induced factors [e.g., hypoxia-inducible factor- $1 \alpha$ (HIF- $1 \alpha)$, neutrophil gelatinase-associated lipocalin (NGAL), to name a few (van Swelm et al. 2018; Zou and Cowley 2003)]. Furthermore, the metabolic profile in the medullary segments shows largely anaerobic glycolysis due to a low partial pressure for $\mathrm{O}_{2}$ (McDonough and Thompson 2012) along with lower abundance of mitochondria. This particular redox status could protect the kidney medulla from $\mathrm{Cd}^{2+}$-induced oxidative stress resulting from mitochondrial damage (Thévenod et al. 2020; Lee et al. 2020), although antioxidant enzyme activities are concomitantly decreased in the medulla compared to the cortex (Thiab et al. 2015).

If hepcidin plays a role in determining cellular iron levels, as supported by the current study, it is imaginable that physiologically hepcidin expressed in the distal nephron could regulate the activity of iron-dependent enzymes and functions, e.g., cellular metabolism, ATP production, ROS formation and/or signaling. Interestingly, the distribution of peroxisomal enzymes, including catalase, along the nephron correlates with that of mitochondria, a major source of cellular ROS formation, as well as of $\mathrm{Na}^{+} / \mathrm{K}^{+}$-ATPase activity (Guder and Ross 1984). Peroxisomes and mitochondria relate functionally, as evidenced by their communication, cooperation and division machinery (Vasko 2016). Thus, hepcidin in the distal nephron could aid to adjust the metabolic and transport demands of the distal nephron under conditions of low tissue $\mathrm{O}_{2}$ partial pressure, as encountered in the kidney medulla. This requires verification in future studies.

In summary, as studied in renal $\mathrm{mIMCD}_{3}$ and $\operatorname{mCCD}(\mathrm{cl} .1)$ cells, hepcidin binds $\mathrm{Fe}^{2+}$ but not $\mathrm{Cd}^{2+}$.
Because $\mathrm{Fe}^{2+}$ and $\mathrm{Cd}^{2+}$ compete for functional binding sites in proteins, hepcidin affects their respective free metal ion pools and impacts differently on downstream processes, such as ROS formation, catalase activity and cell fate (see Fig. 7).

Supplementary Information The online version contains supplementary material available at https://doi.org/10.1007/s00204-021-03106-z.

Acknowledgements Research related to this work was supported by the Deutsche Forschungsgemeinschaft (DFG TH345), a BMBF grant between Germany and Mexico (BMBF 01DN16039) and the Centre for Biomedical Training and Research (ZBAF) of the University of Witten/Herdecke.

Author contributions FT, W-KL and RPLS contributed to the study conception and design. Material preparation, data collection and analysis were performed by all authors. The first draft of the manuscript was written by FT and W-KL and all authors commented on previous versions of the manuscript. All authors read and approved the final manuscript.

Funding Open Access funding enabled and organized by Projekt DEAL. This work was financially supported by Deutsche Forschungsgemeinschaft (DFG TH345), a BMBF grant between Germany and Mexico (BMBF 01DN16039) and the Centre for Biomedical Training and Research (ZBAF) of the University of Witten/Herdecke.

Availability of data and materials The datasets used and/or analyzed during the current study are available from the corresponding authors on reasonable request.

Code availability Not applicable.

\section{Declarations}

Conflict of interest The authors declare that they have no conflicts of interest/competing interests.

Consent for publication Not applicable.

Consent to participate Not applicable.

Ethical approval Not applicable.

Open Access This article is licensed under a Creative Commons Attribution 4.0 International License, which permits use, sharing, adaptation, distribution and reproduction in any medium or format, as long as you give appropriate credit to the original author(s) and the source, provide a link to the Creative Commons licence, and indicate if changes were made. The images or other third party material in this article are included in the article's Creative Commons licence, unless indicated otherwise in a credit line to the material. If material is not included in the article's Creative Commons licence and your intended use is not permitted by statutory regulation or exceeds the permitted use, you will need to obtain permission directly from the copyright holder. To view a copy of this licence, visit http://creativecommons.org/licenses/by/4.0/. 


\section{References}

Abbas IM, Vranic M, Hoffmann H, El-Khatib AH, Montes-Bayon M, Moller HM, Weller MG (2018) Investigations of the copper peptide hepcidin- 25 by LC-MS/MS and NMR. Int J Mol Sci. https:// doi.org/10.3390/ijms19082271

Abouhamed $\mathrm{M}$ et al (2006) Divalent metal transporter 1 in the kidney proximal tubule is expressed in late endosomes/lysosomal membranes: implications for renal handling of protein-metal complexes. Am J Physiol Renal Physiol 290:F1525-F1533. https://doi. org/10.1152/ajprenal.00359.2005

Andreasen D, Jensen BL, Hansen PB, Kwon TH, Nielsen S, Skott $\mathrm{O}(2000)$ The alpha(1G)-subunit of a voltage-dependent $\mathrm{Ca}(2+)$ channel is localized in rat distal nephron and collecting duct. Am J Physiol Renal Physiol 279:F997-F1005. https://doi.org/10.1152/ ajprenal.2000.279.6.F997

Betten R et al (2018) Tonicity inversely modulates lipocalin-2 (Lcn2/24p3/NGAL) receptor (SLC22A17) and Lcn2 expression via $\mathrm{Wnt} /$ beta-catenin signaling in renal inner medullary collecting duct cells: implications for cell fate and bacterial infection. Cell Commun Signal 16:74. https://doi.org/10.1186/ s12964-018-0285-3

Biyani K, Tripathi DK, Lee JH, Muneer S (2019) Dynamic role of iron supply in amelioration of cadmium stress by modulating antioxidative pathways and peroxidase enzymes in mungbean. AoB Plants 11:plz005. https://doi.org/10.1093/aobpla/plz005

Bradford MM (1976) A rapid and sensitive method for the quantitation of microgram quantities of protein utilizing the principle of protein-dye binding. Anal Biochem 72:248-254. https://doi. org/10.1006/abio.1976.9999

Bustin SA et al (2009) The MIQE guidelines: minimum information for publication of quantitative real-time PCR experiments. Clin Chem 55:611-622. https://doi.org/10.1373/clinchem.2008. 112797

Campos R, Maureira F, Garrido A, Valenzuela A (1993) Different glutathione redox status and lipid peroxidation in the cortex and the medulla of the rat kidney subjected to ischemia-reperfusion stress . Comp Biochem Physiol B Comp Biochem 105:157-163. https://doi.org/10.1016/0305-0491(93)90183-6

Cuypers A et al (2010) Cadmium stress: an oxidative challenge. Biometals 23:927-940. https://doi.org/10.1007/s10534-010-9329-x

Deisseroth A, Dounce AL (1970) Catalase: Physical and chemical properties, mechanism of catalysis, and physiological role. Physiol Rev 50:319-375. https://doi.org/10.1152/physrev.1970. 50.3.319

Dixon SJ, Stockwell BR (2014) The role of iron and reactive oxygen species in cell death. Nat Chem Biol 10:9-17. https://doi.org/10. 1038/nchembio. 1416

El Mouatassim S, Guerin P, Menezo Y (1999) Expression of genes encoding antioxidant enzymes in human and mouse oocytes during the final stages of maturation. Mol Hum Reprod 5:720-725. https://doi.org/10.1093/molehr/5.8.720

Farnaud S, Patel A, Evans RW (2006) Modelling of a metal-containing hepcidin. Biometals 19:527-533. https://doi.org/10.1007/ s10534-005-5883-z

Farnaud S, Rapisarda C, Bui T, Drake A, Cammack R, Evans RW (2008) Identification of an iron-hepcidin complex. Biochem J 413:553-557. https://doi.org/10.1042/BJ20080406

Ferguson CJ, Wareing M, Ward DT, Green R, Smith CP, Riccardi D (2001) Cellular localization of divalent metal transporter DMT-1 in rat kidney. Am J Physiol Renal Physiol 280:F803-F814. https:// doi.org/10.1152/ajprenal.2001.280.5.F803

Fila M, Brideau G, Morla L, Cheval L, Deschenes G, Doucet A (2011) Inhibition of $\mathrm{K}+$ secretion in the distal nephron in nephrotic syndrome: possible role of albuminuria. J Physiol 589:3611-3621. https://doi.org/10.1113/jphysiol.2011.209692

Freisinger E, Vasak M (2013) Cadmium in metallothioneins. Met Ions Life Sci 11:339-371. https://doi.org/10.1007/978-94-007-5179811

Gaeggeler HP et al (2005) Mineralocorticoid versus glucocorticoid receptor occupancy mediating aldosterone-stimulated sodium transport in a novel renal cell line. J Am Soc Nephrol 16:878-891. https://doi.org/10.1681/ASN.2004121110

Ganz T, Nemeth E (2012) Hepcidin and iron homeostasis. Biochim Biophys Acta 1823:1434-1443. https://doi.org/10.1016/j.bbamcr. 2012.01.014

Gerardi G et al (2005) Recombinant human hepcidin expressed in Escherichia coli isolates as an iron containing protein. Blood Cells Mol Dis 35:177-181. https://doi.org/10.1016/j.bcmd.2005.06.002

Gonzalez-Flecha B, Evelson P, Sterin-Speziale N, Boveris A (1993) Hydrogen peroxide metabolism and oxidative stress in cortical, medullary and papillary zones of rat kidney. Biochim Biophys Acta 1157:155-161. https://doi.org/10.1172/JCI116223

Guder WG, Ross BD (1984) Enzyme distribution along the nephron. Kidney Int 26:101-111. https://doi.org/10.1038/ki.1984.143

Halliwell B, Gutteridge JM (2015) Free radicals in biology and medicine, 5th edn. Oxford University Press, Oxford

Harrington JM, Boyd WA, Smith MV, Rice JR, Freedman JH, Crumbliss AL (2012) Amelioration of metal-induced toxicity in Caenorhabditis elegans: utility of chelating agents in the bioremediation of metals. Toxicol Sci 129:49-56. https://doi.org/10. 1093/toxsci/kfs 191

Jarup L, Akesson A (2009) Current status of cadmium as an environmental health problem. Toxicol Appl Pharmacol 238:201-208. https://doi.org/10.1016/j.taap.2009.04.020

Johri N, Jacquillet G, Unwin R (2010) Heavy metal poisoning: the effects of cadmium on the kidney. Biometals 23:783-792. https:// doi.org/10.1007/s10534-010-9328-y

Kakhlon O, Cabantchik ZI (2002) The labile iron pool: characterization, measurement, and participation in cellular processes(1). Free Radic Biol Med 33:1037-1046. https://doi.org/10.1016/ s0891-5849(02)01006-7

Kalmbach P, Fahimi HD (1978) Peroxisomes: identification in freezeetch preparations of rat kidney. Cell Biol Int Rep 2:389-396. https://doi.org/10.1016/0309-1651(78)90025-5

Kanamori Y, Murakami M, Matsui T, Funaba M (2014) Hepcidin expression in liver cells: evaluation of mRNA levels and transcriptional regulation. Gene 546:50-55. https://doi.org/10.1016/j. gene.2014.05.040

Keberle H (1964) The biochemistry of desferrioxamine and its relation to iron metabolism. Ann N Y Acad Sci 119:758-768. https://doi. org/10.1111/j.1749-6632.1965.tb54077.x

Klaassen CD, Liu J, Diwan BA (2009) Metallothionein protection of cadmium toxicity. Toxicol Appl Pharmacol 238:215-220. https:// doi.org/10.1016/j.taap.2009.03.026

Kulaksiz H et al (2005) The iron-regulatory peptide hormone hepcidin: expression and cellular localization in the mammalian kidney. $\mathbf{J}$ Endocrinol 184:361-370. https://doi.org/10.1677/joe.1.05729

Landing BH et al (1989) Renal lesions and clinical findings in thalassemia major and other chronic anemias with hemosiderosis. Pediatr Pathol 9:479-500. https://doi.org/10.3109/155138189090269 08

Lee WK, Bork U, Gholamrezaei F, Thévenod F (2005) Cd(2+)-induced cytochrome c release in apoptotic proximal tubule cells: role of mitochondrial permeability transition pore and $\mathrm{Ca}(2+)$ uniporter. Am J Physiol Renal Physiol 288:F27-F39. https://doi.org/10. 1152/ajprenal.00224.2004

Lee JW, Chou CL, Knepper MA (2015) Deep sequencing in microdissected renal tubules identifies nephron segment-specific 
transcriptomes. J Am Soc Nephrol 26:2669-2677. https://doi. org/10.1681/ASN.2014111067

Lee WK, Thévenod F (2020) Cell organelles as targets of mammalian cadmium toxicity. Arch Toxicol 94(4):1017-1049. https://doi. org/10.1007/s00204-020-02692-8. Epub 2020 Mar 23. PMID: 32206829

Limaye PV, Raghuram N, Sivakami S (2003) Oxidative stress and gene expression of antioxidant enzymes in the renal cortex of streptozotocin-induced diabetic rats. Mol Cell Biochem 243:147-152. https://doi.org/10.1023/a:1021620414979

Litwin JA, Volkl A, Stachura J, Fahimi HD (1988) Detection of peroxisomes in human liver and kidney fixed with formalin and embedded in paraffin: the use of catalase and lipid beta-oxidation enzymes as immunocytochemical markers. Histochem J 20:165173. https://doi.org/10.1007/BF01746680

Lopin KV, Gray IP, Obejero-Paz CA, Thévenod F, Jones SW (2012a) $\mathrm{Fe}(2)(+)$ block and permeation of CaV3.1 (alpha1G) T-type calcium channels: candidate mechanism for non-transferrin-mediated $\mathrm{Fe}(2)(+)$ influx. Mol Pharmacol 82:1194-1204. https://doi.org/10. 1124/mol.112.080184

Lopin KV, Thévenod F, Page JC, Jones SW (2012b) Cd(2)(+) block and permeation of CaV3.1 (alpha1G) T-type calcium channels: candidate mechanism for $\mathrm{Cd}(2)(+)$ influx. Mol Pharmacol 82:1183-1193. https://doi.org/10.1124/mol.112.080176

Macdougall LG (1972) Red cell metabolism in iron deficiency anemia. 3. The relationship between glutathione peroxidase, catalase, serum vitamin E, and susceptibility of iron-deficient red cells to oxidative hemolysis. J Pediatr 80:775-782. https://doi.org/10. 1016/s0022-3476(72)80130-6

Martines AM, Masereeuw R, Tjalsma H, Hoenderop JG, Wetzels JF, Swinkels DW (2013) Iron metabolism in the pathogenesis of ironinduced kidney injury. Nat Rev Nephrol 9:385-398. https://doi. org/10.1038/nrneph.2013.98

McDonough AA, Thompson SC (2012) Metabolic basis of solute transport. In: Taal MW, Chertow GM, Marsden PA, Skorecki K, Yu ASL, Brenner BM (eds) Brenner \& Rector's The Kidney, vol 1, 9 edn. Saunders, Philadelphia, pp 138-157

Millonig G et al (2012) Sustained submicromolar H2O2 levels induce hepcidin via signal transducer and activator of transcription 3 (STAT3). J Biol Chem 287:37472-37482. https://doi.org/10.1074/ jbc.M112.358911

Moulis JM (2010) Cellular mechanisms of cadmium toxicity related to the homeostasis of essential metals. Biometals 23:877-896. https://doi.org/10.1007/s10534-010-9336-y

Moulouel B et al (2013) Hepcidin regulates intrarenal iron handling at the distal nephron. Kidney Int 84:756-766. https://doi.org/10. 1038/ki.2013.142

Muse KE, Oberley TD, Sempf JM, Oberley LW (1994) Immunolocalization of antioxidant enzymes in adult hamster kidney. Histochem J 26:734-753. https://doi.org/10.1007/BF00158205

Nagamine $T$ et al (2007) Analysis of tissue cadmium distribution in chronic cadmium-exposed mice using in-air micro-PIXE. Biol Trace Elem Res 117:115-126. https://doi.org/10.1007/BF026 98088

Nair AR, Lee WK, Smeets K, Swennen Q, Sanchez A, Thévenod F, Cuypers A (2015) Glutathione and mitochondria determine acute defense responses and adaptive processes in cadmium-induced oxidative stress and toxicity of the kidney. Arch Toxicol 89:22732289. https://doi.org/10.1007/s00204-014-1401-9

Nemeth E et al (2004) Hepcidin regulates cellular iron efflux by binding to ferroportin and inducing its internalization. Science 306:2090-2093. https://doi.org/10.1126/science.1104742

Pardo-Mindan FJ, Diez J, Esparza N, Robledo C (1990) Renal siderosis in patients with heart-valve prostheses: clinical implications. Nephrol Dial Transplant 5:847-850. https://doi.org/10.1093/ndt/5. 10.847
Piloni NE, Perazzo JC, Fernandez V, Videla LA, Puntarulo S (2016) Sub-chronic iron overload triggers oxidative stress development in rat brain: implications for cell protection. Biometals 29:119-130. https://doi.org/10.1007/s10534-015-9902-4

Prozialeck WC, Edwards JR (2012) Mechanisms of cadmium-induced proximal tubule injury: new insights with implications for biomonitoring and therapeutic interventions. J Pharmacol Exp Ther 343:2-12. https://doi.org/10.1124/jpet.110.166769

Ratliff BB, Abdulmahdi W, Pawar R, Wolin MS (2016) Oxidant mechanisms in renal injury and disease. Antioxid Redox Signal 25:119-146. https://doi.org/10.1089/ars.2016.6665

Rauchman MI, Nigam SK, Delpire E, Gullans SR (1993) An osmotically tolerant inner medullary collecting duct cell line from an SV40 transgenic mouse. Am J Physiol 265:F416-F424. https:// doi.org/10.1152/ajprenal.1993.265.3.F416

Richter GW (1980) Iron overload nephropathy in rats. Pathol Res Pract 168:84-106. https://doi.org/10.1016/S0344-0338(80)80209-3

Ruttkay-Nedecky B et al (2013) The role of metallothionein in oxidative stress. Int J Mol Sci 14:6044-6066. https://doi.org/10.3390/ ijms 14036044

Sabolic I, Breljak D, Skarica M, Herak-Kramberger CM (2010) Role of metallothionein in cadmium traffic and toxicity in kidneys and other mammalian organs. Biometals 23:897-926. https://doi.org/ 10.1007/s10534-010-9351-z

Schindelin J et al (2012) Fiji: an open-source platform for biologicalimage analysis. Nat Methods 9:676-682. https://doi.org/10.1038/ nmeth.2019

Schneider CA, Rasband WS, Eliceiri KW (2012) NIH Image to ImageJ: 25 years of image analysis. Nat Methods 9:671-675. https://doi. org/10.1038/nmeth.2089

Schultze MO, Kuiken KA (1941) The effect of deficiencies in copper and iron on the catalase activity of rat tissues. J Biol Chem 137:727-734

Scindia Y et al (2015) Hepcidin mitigates renal ischemia-reperfusion injury by modulating systemic iron homeostasis. J Am Soc Nephrol 26:2800-2814. https://doi.org/10.1681/ASN.20141 01037

Smith CP, Thévenod F (2009) Iron transport and the kidney. Biochim Biophys Acta 1790:724-730. https://doi.org/10.1016/j.bbagen. 2008.10.010

Srigiridhar K, Nair KM (1998) Iron-deficient intestine is more susceptible to peroxidative damage during iron supplementation in rats. Free Radic Biol Med 25:660-665. https://doi.org/10.1016/ s0891-5849(98)00086-0

Thévenod F (2003) Nephrotoxicity and the proximal tubule. Insights from Cadmium. Nephron Physiol 93:87-93. https://doi.org/10. $1159 / 000070241$

Thévenod F (2009) Cadmium and cellular signaling cascades: To be or not to be? Toxicol Appl Pharmacol 238:221-239. https://doi. org/10.1016/j.taap.2009.01.013

Thévenod F, Wolff NA (2016) Iron transport in the kidney: implications for physiology and cadmium nephrotoxicity. Metallomics 8:17-42. https://doi.org/10.1039/c5mt00215j

Thévenod F, Fels J, Lee WK, Zarbock R (2019) Channels, transporters and receptors for cadmium and cadmium complexes in eukaryotic cells: myths and facts. Biometals 32:469-489. https://doi.org/10. 1007/s10534-019-00176-6

Thévenod F, Lee WK, Garrick MD (2020) Iron and cadmium entry into renal mitochondria: physiological and toxicological implications Front Cell. Dev Biol 8:848. https://doi.org/10.3389/fcell. 2020.00848

Thiab NR, King N, Jones GL (2015) Effects of ageing on metabolite and oxidant concentrations in different regions of rat kidney under normal and stress conditions. Mol Cell Biochem 408:55-61. https://doi.org/10.1007/s11010-015-2482-3 
Torra M, To-Figueras J, Brunet M, Rodamilans M, Corbella J (1994) Total and metallothionein-bound cadmium in the liver and the kidney of a population in Barcelona (Spain). Bull Environ Contam Toxicol 53:509-515. https://doi.org/10.1007/BF00199019

van Swelm RP et al (2016) Renal handling of circulating and renal-synthesized hepcidin and its protective effects against hemoglobinmediated kidney injury. J Am Soc Nephrol 27:2720-2732. https:// doi.org/10.1681/ASN.2015040461

van Swelm RPL, Vos M, Verhoeven F, Thévenod F, Swinkels DW (2018) Endogenous hepcidin synthesis protects the distal nephron against hemin and hemoglobin mediated necroptosis. Cell Death Dis 9:550. https://doi.org/10.1038/s41419-018-0568-z

van Swelm RPL, Wetzels JFM, Swinkels DW (2020) The multifaceted role of iron in renal health and disease. Nat Rev Nephrol 16:77-98. https://doi.org/10.1038/s41581-019-0197-5

Vasko R (2016) Peroxisomes and Kidney Injury. Antioxid Redox Signal 25:217-231. https://doi.org/10.1089/ars.2016.6666

Waalkes MP, Harvey MJ, Klaassen CD (1984) Relative in vitro affinity of hepatic metallothionein for metals. Toxicol Lett 20:33-39. https://doi.org/10.1016/0378-4274(84)90179-6

Wang L, Chen D, Wang H, Liu Z (2009) Effects of lead and/or cadmium on the expression of metallothionein in the kidney of rats. Biol Trace Elem Res 129:190-199. https://doi.org/10.1007/ s12011-008-8288-3

Wareing $\mathrm{M}$ et al (2003) Altered dietary iron intake is a strong modulator of renal DMT1 expression. Am J Physiol Renal Physiol 285:F1050-F1059. https://doi.org/10.1152/ajprenal.00064.2003

Wolff NA, Abouhamed M, Verroust PJ, Thévenod F (2006) Megalin-dependent internalization of cadmium-metallothionein and cytotoxicity in cultured renal proximal tubule cells. J Pharmacol Exp Ther 318:782-791. https://doi.org/10.1124/jpet.106.102574

Wolff NA, Lee WK, Abouhamed M, Thévenod F (2008) Role of ARF6 in internalization of metal-binding proteins, metallothionein and transferrin, and cadmium-metallothionein toxicity in kidney proximal tubule cells. Toxicol Appl Pharmacol 230:78-85. https://doi. org/10.1016/j.taap.2008.02.008

Woost PG, Orosz DE, Jin W, Frisa PS, Jacobberger JW, Douglas JG, Hopfer U (1996) Immortalization and characterization of proximal tubule cells derived from kidneys of spontaneously hypertensive and normotensive rats. Kidney Int 50:125-134. https://doi.org/ 10.1038/ki.1996.295

Yoshida M, Ohta H, Yamauchi Y, Seki Y, Sagi M, Yamazaki K, Sumi Y (1998) Age-dependent changes in metallothionein levels in liver and kidney of the Japanese. Biol Trace Elem Res 63:167-175. https://doi.org/10.1007/BF02778875

Zainal TA, Weindruch R, Szweda LI, Oberley TD (1999) Localization of 4-hydroxy-2-nonenal-modified proteins in kidney following iron overload. Free Radic Biol Med 26:1181-1193. https://doi. org/10.1016/s0891-5849(98)00312-8

Zou AP, Cowley AW Jr (2003) Reactive oxygen species and molecular regulation of renal oxygenation. Acta Physiol Scand 179:233-241. https://doi.org/10.1046/j.0001-6772.2003.01206.x

Publisher's Note Springer Nature remains neutral with regard to jurisdictional claims in published maps and institutional affiliations. 